\title{
Protestos contra e a favor do impeachment de 2016 no Facebook: uma análise das páginas do MBL e Frente Brasil Popular
}

\author{
Protests for and against the 2016 impeachment on Facebook: an \\ analysis of MBL and Frente Brasil Popular pages
}

Protestas en contra y a favor del impeachment de 2016 em Facebook: un análisis de las páginas de MBL y Frente Brasil Popular

Recebido em 31-08-2020

Modificado em 24-12-2020

Aprovado em 13-03-2021

\section{doi}

https://doi.org/10.47456/simbitica.v8i2.36383

\section{Maria Alice Silveira Ferreira}

ORCID: 0000-0003-4679-4443

Doutoranda e Mestra em Ciência Política pela Universidade Federal de Minas Gerais, Brasil. Bolsista do INCTInstituto da Democracia e da Democratização da Comunicação. Pesquisadora do CEPPI-UFMG. E-mail: m.alicesilveira@gmail.com

\section{Helga do Nascimento Almeida}

ORCID: 0000-0001-7245-4288

Doutora e mestra em ciência política pela Universidade Federal de Minas Gerais, Brasil. Professora adjunta da Universidade Federal do Vale do São Francisco. Professora permanente do Programa de Pós-Graduação em Ciência Política da Universidade Federal do Piauí. Pesquisadora do CEPPI-UFMG. E-mail: helgaalmeida@gmail.com

\section{Resumo}

Este trabalho buscou identificar a dinâmica de mobilização em páginas de espectros políticos distintos durante período de protestos. Para tanto, foi realizada uma análise de conteúdo das páginas no Facebook do Movimento Brasil Livre e Frente Brasil Popular com o objetivo de entender as estratégias de comunicação e uso de affordances dessas páginas entre março e abril de 2016, período marcado por intensas manifestações contra e a favor ao impeachment de Dilma Rousseff. Na análise, procurou-se identificar os seguintes elementos: 1) número de postagens; 2) engajamento; 3) conteúdo postado; 4) assuntos abordados; 5) postagens com referência à Presidenta Dilma; 6) uso de hashtags; 7) fontes; 8) tipo de mídias e 9) convites para a doação e participação no movimento. Concluiu-se que houve estratégias bem diferentes no uso das affordances comparados os dois movimentos.

Palavras-chave: impeachment; Frente Brasil Popular; Movimento Brasil Livre; Facebook. 


\section{Introdução}

Desde 2013, o Brasil tem vivido uma grande onda de manifestações em larga escala e uma forte polarização política (Santiago; Von Bülow; Dias; Gomes, 2017; Avritzer, 2017; Mendonça, 2017). Os acontecimentos políticos dos últimos anos têm mostrado uma crise política que se intensificou em dezembro de 2015, com o acolhimento do pedido de impeachment da Presidenta Dilma Rousseff. O pedido de impeachment foi um momento importante que mobilizou pessoas e grupos políticos que se posicionavam contra e a favor da saída da presidenta. Os meses de março e abril de 2016 - período que antecedeu a votação da admissibilidade do processo no Congresso - foram marcados com intensas disputas. Hashtags e mobilizações em torno do \#ForaDilma; \#EsseImpeachmentÉMeu; \#NãoVaiTerGolpe e \#VempraDemocracia mobilizaram tanto pessoas nas ruas, com diversas manifestações, quanto nas mídias sociais em torno de uma disputa de narrativas.

Este trabalho propõe uma análise das páginas do Movimento Brasil Livre ${ }^{1}$ e Frente Brasil Popular ${ }^{2}$, importantes grupos que articularam as manifestações de rua no Brasil durante os meses de março e abril de 2016. Por meio de técnicas de análise de conteúdo, buscou-se entender as estratégias de comunicação e uso de affordances das duas páginas durante o período de votação do impeachment da presidenta Dilma Rousseff - marcado por intensas mobilizações online e offline contra e a favor da saída da presidenta. A intenção foi escolher duas páginas representativas de pensamentos políticos com posicionamentos pertencentes a ambos os lados do espectro ideológico, tanto à direita quanto à esquerda, o que possibilita entender comparativamente como esses dois grupos distintos mobilizam seus conteúdos e argumentos em suas páginas em um contexto político polarizado.

Para este trabalho foram criadas as seguintes categorias de análise: 1) número de postagens feitas; 2) engajamento nas postagens; 3) tipo de conteúdo postado; 4) assuntos abordados; 5) postagens com referência à Presidenta Dilma; 6) uso de hashtags; 7) fontes de conteúdo usadas pela página; 8) tipos de mídias usadas nas postagens e 9) convites para a doação e participação no movimento. Partimos da ideia de Gerbaudo (2016a) de vanguardas digitais, onde equipes que gerenciam as mídias sociais produzem conteúdos que alimentam os usuários - a multidão. No Facebook, essas vanguardas trabalham publicando vídeos, fotos e eventos, respondendo os usuários e moderando as páginas. A relação entre as vanguardas e a multidão se retroalimenta. No caso das vanguardas representadas pelo Movimento Brasil

\footnotetext{
${ }^{1}$ Disponível em https://www.facebook.com/mblivre/?ref=br_rs. Acesso em 13 out. 2017.

${ }^{2}$ Disponível em https://www.facebook.com/FrenteBrasilPopular/. Acesso em 13 de out. 2017.
} 
Livre e pela Frente Brasil Popular, pôde-se observar a construção de modus operandi diferentes e mobilização de estratégias diversas, como se será possível ver ao longo do texto.

\section{Mídias sociais e ação coletiva}

A grande onda de protestos (McAdam; Tarrow; Tilly, 2001; Tilly, 2006; 2008; Tarrow, 2013) em larga escala nos últimos anos tem chamado atenção de pesquisadores e da opinião pública sobre importantes mudanças nas dinâmicas e formas da ação política de confronto. Atualmente, discussões políticas, bem como a convocação e organização para ações de protestos, têm passado, muitas vezes, pela internet e, principalmente, pelas mídias sociais, tais como Facebook, Twitter, Whatsapp entre outras. É bastante comum vermos campanhas em favor de alguma causa, contra alguma legislação ou decisão do governo e convocações para protestos face a face.

A literatura sobre internet e política, em especial sobre ação coletiva, já reconhece o papel dessas redes digitais nos protestos e movimentos sociais (Castells, 2001; 2014; Bennett; Segerberg, 2013; Pereira, 2011; Ferreira, 2015, Milan, 2015) e os desafios que essas mudanças trazem para ação coletiva. Isso porque os usos da internet e mídias sociais para a ação política sugerem que o escopo da ação coletiva guiado pela teoria deve ser expandido para tentar incorporar essas novas formas de ação, juntamente com as ações tradicionais (Bimber; Stohl; Flanagin, 2009).

Fato é que na contemporaneidade a luta política não tem ocorrido só pela luta nas ruas, mas também por uma luta de significados que tem se passado, em grande parte, pelas mídias digitais. Com a popularização de smartphones e tablets, os usos dessas mídias se intensificaram ainda mais e, hoje em dia, estar conectado o tempo todo nessas plataformas faz parte do cotidiano das pessoas. Essas mídias tornam-se um extenso espaço de recreação e conversas cotidianas, onde as pessoas podem falar sobre as suas vidas, mostrar fotos de viagens, passeios etc. (Cardon, 2012; Van Dijck, 2012). Nesse mesmo espaço, as pessoas também falam sobre política, participam de discussões e outros assuntos não triviais. Elas fazem amizades e estabelecem contato com os laços fortes (família, amigos) e com os laços fracos (colegas, conhecidos). De acordo com Van Dijck (2012), essas plataformas digitais geram um fluxo contínuo de comunicação informal (ideias, gostos, interesses, notícias etc.) e têm se transformado num importante espaço de comunicação.

Van Dijck e Poell (2013) consideram a mídia social como um conjunto de aplicativos na internet que se baseiam nos fundamentos da web 2.0 e que permitem tanto a criação como 
a troca de conteúdo de um usuário (Kaplan; Haenlein, 2011 apud Van Dijck; Poell, 2013). Dessa forma, os autores apontam que a lógica da mídia social diz respeito aos processos, princípios e práticas onde essas plataformas processam informações, notícias e comunicações e como canalizam o tráfego social. Van Dijck e Poell (2013) afirmam que as mídias sociais estão longe de ser plataformas neutras e que elas afetam as condições e regras de interação social.

De acordo com Lim, (2012) as mídias sociais são fundamentais na mobilização. Elas podem ser vistas tanto como tecnologia quanto espaço para expandir e sustentar as redes das quais dependem os movimentos sociais. Para Bennett, Segerberg e Walker (2014) os protestos se comportam como redes híbridas e essas redes têm sido capazes de produzir propriedades organizacionais. As redes digitais, então, seriam pontes para transcender suas interações face a face (Bennett; Segerberg; Walker, 2014). As revoltas árabes, por exemplo, mostram como as redes sociais online facilitadas pelas mídias sociais tornaram-se um ingrediente-chave dos movimentos contemporâneos.

Dessa forma, entendemos que as ações políticas da atualidade estão sendo fundamentalmente afetadas pelas mídias sociais. De acordo com Milan (2015), essas mídias têm se tornado curadores dos discursos públicos, alterando práticas, discursos e dinâmicas da ação coletiva, como o protesto, por exemplo. Elas não só transmitem, mas produzem sociabilidade e possibilitam conexões (Van Dijck, 2013 apud Milan, 2015). A difusão da internet e das mídias sociais faz desses espaços locais de criação, modulação e ampliação de repertórios discursivos (Tarrow, 2013). Os manifestantes interagem e se articulam por meio de mensagens e imagens nas plataformas e mídias sociais. As palavras refletem o contexto das mudanças sociais e políticas. Com as mídias sociais, mudanças ocorrem quase que instantaneamente e em grande volume.

\section{A ação conectiva e o protesto em nuvem: as mídias sociais como atores}

Autores como Bennett e Segerberg (2013) e Milan (2015) têm feito esforços em tentar entender como as tecnologias têm modificado e moldado as formas de ação coletiva, elaborando conceitos como ação conectiva e protesto em nuvem, respectivamente. Os autores reconhecem que a internet e as mídias sociais têm trazido novas configurações na ação política e uma característica importante apontada pelos autores é uma maior personalização das lutas políticas (Mendonça, 2017; Bennett; Segerberg, 2013; Milan, 2015). Ou seja, cada vez mais, as pessoas são capazes de expressar esperanças, estilos de vidas e queixas. As 
tecnologias, por sua vez, são capazes de unir indivíduos e suas queixas que se encontram isolados (Bennett; Segerberg, 2013).

Na ação conectiva, elaborada por Bennett e Segerberg (2013), as ações de confronto: 1) conseguem se ampliar rapidamente; 2) produzem largas mobilizações; 3) têm maior flexibilidade em rastrear alvos políticos e fazer pontes entre diferentes questões; e 4) possuem capacidade de construir repertórios de protestos adaptáveis. Essas características estão relacionadas a ações digitalmente mediadas e quadros de ações pessoais, ou seja, um engajamento político mais personalizável.

Stephania Milan (2015) aponta que a ideia de ação conectiva, apesar de inovadora, tem limitações ao não levar em conta o caráter algorítmico dessas redes. As mídias sociais são mídias moldadas a partir de processos algorítmicos. Os algoritmos - códigos em execução que operam por meios de rotinas programadas (Milan, 2015) -, têm aprimorado sua capacidade preditiva em relação a gostos, comportamentos e emoções dos usuários das mídias sociais (Sunstein, 2018). Eles têm sido capazes de classificar os usuários de acordo com os seus comportamentos e selecionam e personalizam conteúdo de acordo com os dados.

Uma das ações possibilitadas pelos algoritmos nas mídias sociais é a criação das chamadas bolhas (Pariser, 2012). As bolhas são mecanismos que filtram e refinam a informação para atender cada indivíduo especificamente, criando um universo exclusivo de informação para cada pessoa (Pariser, 2012). A grande questão que se diz sobre as bolhas é que elas podem afetar nossa capacidade de decisão, trazendo menos encontros e aprendizados diferentes. Elas possibilitam o compartilhamento e intensificam os mesmos gostos e opiniões, gerando emoções e sentimentos em comum entre aqueles que pertencem a uma mesma bolha, mas também criam sentimentos de repulsa em relação aos que estão fora dela.

Sunstein (2018) também afirma que a internet e as mídias sociais têm criado, cada vez mais, nichos específicos, e isso facilita a fragmentação e a polarização. Esses nichos, por sua vez, têm virado câmaras de eco, onde as pessoas visualizam só discursos semelhantes aos seus e dialogam somente com opiniões parecidas com as suas. Segundo o autor, uma tendência nesses processos é o que ele chama de "polarização de grupo". Ou seja, uma vez polarizadas, as pessoas tendem a se direcionar para onde estão mais inclinadas. Para ele, os indivíduos podem até fazer escolhas, mas acabam caindo suas próprias câmaras de eco. No Facebook e Twitter, por exemplo, as pessoas têm criado suas próprias câmaras de eco em seus feeds de notícias, onde elas podem confirmar suas próprias visões. Isso é suficiente para gerar a polarização e fragmentação e pode ser perigoso para a democracia, uma vez que as pessoas vão ficando cada vez menos propensas às visões opostas, levando a extremismos. 
Levando em consideração o caráter algorítmico dessas mídias e as consequências que isso pode trazer, Milan (2015) considera que é criada, então, uma lógica de comunicação que tem o poder de conduzir a ação social. Dessa forma, a autora elabora o conceito do protesto em nuvem, que diz respeito um tipo de mobilização centrada nos indivíduos e suas necessidades, identidades e corpos. Ele é construído e moldado por plataformas de mídias sociais e dispositivos móveis e os universos digitais que eles identificam.

Além disso, Milan (2015) aponta que a identidade coletiva está no centro das manifestações contemporâneas digitalmente mediadas. Para a autora, a lógica dessas mídias é capaz de estender e remodelar os processos em que a identidade coletiva é criada, reproduzida e mantida. A mídia tem, então, um papel fundamental na formação do "nós".

Dessa forma, a autora aponta que é criada uma lógica de comunicação que tem o poder de conduzir a ação social. As mídias sociais não são mais meras plataformas, mas tornaram-se atores por direito próprio, intervindo no processo de criação de significados dos atores sociais por meio de seu poder algorítmico. Eles são capazes de modificar e manipular conteúdo por meio de rotinas programadas. Essa modificação e manipulação muitas vezes é feita sem o controle dos usuários (Mckelvey, 2014; Van Dijck; Poell, 2013; Beer, 2009 apud Milan, 2015).

Para Milan (2015), as mídias sociais desempenham um novo papel de corretor no processo de construção de significados dos ativistas. "Elas funcionam como 'associações tecnoculturais que trabalham com e por meio de sinais para organizar as mediações e traduções entre dados, informação e símbolos linguísticos', promovendo regimes específicos de produção e circulação de sentido" (Langlois, 2011 apud Milan, 2015: 04).

Dessa forma, os links que conectam as diversas plataformas digitais se tornam importantes para engajar participantes e coordenar relações. Nesse sentido, a comunicação e as affordances das mídias digitais são centrais para essas ações. Affordance diz respeito a um tipo ou característica de ação que uma tecnologia pode possibilitar pelo seu formato (Earl; Kimport, 2011). Assim, cada mídia social possui affordances específicas que podem colocar restrições ou oportunidades na produção simbólica e organizacional da ação política (Milan, 2015).

De acordo com Gerbaudo (2016a) a estrutura das mídias sociais pode ser entendida a partir da ideia de vanguardas digitais e multidões. Para o autor, vanguardas digitais são “estruturas de lideranças coletivas e informais que moldam o papel da direção da ação coletiva por meio do uso da comunicação digital" (Gerbaudo, 2016a). Essas vanguardas são compostas por equipes de pessoas que gerenciam as contas nas mídias sociais, os 
administradores. São eles que publicam, criam conteúdos, agendam e editam mensagens, além de interagir com os usuários. A relação entre as vanguardas e a multidão se retroalimenta. Para Gerbaudo (2016b), a comunicação motivacional produzida pelos administradores de contas teria tido pouco efeito não fosse a receptividade e cooperação desses usuários.

O autor ainda destaca que ao procurar entender sobre essas equipes de mídia social é possível entender também outras nuances do movimento, como sua estrutura organizacional, por exemplo, o que muitas vezes pode contrapor com a ideia de que nesses movimentos não há lideranças, ou que não são hierárquicos.

As vanguardas digitais são, então, grupos políticos que atuam como centros organizadores de movimentos sociais por meio do uso da comunicação digital. O termo tenta mostrar que grupos relativamente pequenos que são responsáveis por gerir as mídias sociais são capazes de gerar uma "função de vanguarda" (Nunes, 2014 apud Gerbaudo, 2016b) que direciona ação coletiva escrevendo tweets, mensagens de status, respondendo usuários e moderando as conversas.

Gerbaudo (2016a) ainda aponta ainda que a vanguarda digital possui um caráter coletivo e participativo. As lideranças, tradicionalmente, como afirma Gerbaudo, sempre estiveram relacionadas a líderes individuais. A vanguarda digital muitas vezes é composta por uma equipe que inclui jornalistas, designers, segurança, informática, organização, gerenciamento de comunidade on-line e moderação, tornando assim, praticamente impossível para apenas um indivíduo executar com sucesso uma conta ativista.

\section{O impeachment da Presidenta Dilma Rousseff e os protestos de 2016}

O Brasil tem atravessado uma forte crise política desde 2013 com importantes acontecimentos. Esses acontecimentos, por sua vez, têm sido marcados por intensos protestos em larga escala, que têm levado milhares de brasileiros às ruas para se manifestarem. Muitas foram as manifestações que ocorreram no país desde o ciclo de protestos que se iniciou em 2013. Junho de 2013, amplamente conhecido, levou pessoas às ruas reivindicando o fim da corrupção, melhorias na saúde, educação entre outras pautas (Ferreira, 2015). Em 2014, os protestos continuaram a mobilizar as pessoas contra o governo de Dilma Rousseff. Após a reeleição da presidenta, os protestos contra o governo continuaram e se intensificaram em 
2015, pedindo a saída de Dilma. Como já foi dito aqui, os anos de 2015 e 2016 foram marcados por inúmeras manifestações contra e favor a saída da presidenta ${ }^{3}$.

As grandes manifestações de rua continuaram nos anos seguintes. Os protestos entre 2016 e 2019 tiveram pautas diversas e de ambos os espectros ideológicos, mostrando como a sociedade brasileira ainda se mantém polarizada. Dentre as inúmeras manifestações podemos destacar algumas: protestos contra a PEC dos gastos públicos (PEC 55) (Ferreira; Crepalde, 2017); contra a eleição do então presidente Jair Bolsonaro (\#EleNão) (Ferreira; Pereira; 2019); a favor do presidente Jair Bolsonaro e contra o Supremo Tribunal Federal (STF); a favor da Operação Lava a Jato e contra os cortes na educação.

Este trabalho, no entanto, focou-se num período específico da vida política brasileira, os meses de março e abril de 2016, marcados por intensas mobilizações contra e a favor da saída da presidenta da república, Dilma Rousseff. A forte polarização política (Santiago; Von Bulow; Dias; Gomes, 2017; Avritzer, 2017; Mendonça, 2017) que vem acompanhando esses acontecimentos dividiu grupos da sociedade brasileira entre aqueles que acreditavam que a presidenta deveria ser impedida e aqueles que acreditavam que a presidenta deveria continuar o mandato e que o impeachment, da forma que estava sendo desenhado, era um golpe à democracia brasileira (Dos Santos, 2017).

O processo para a saída da presidenta se iniciou no final de 2015 com o acolhimento do pedido de impeachment pelo então presidente da Câmara dos Deputados, Eduardo Cunha. Foi dentro desse contexto que as pessoas ocuparam as ruas para protestar a favor e contra a saída da presidenta. Para além disso, houve uma intensa disputa nas mídias sociais entre as narrativas do \#ForaDilma e \#NãoVaiTerGolpe (Dias, 2016). Ao todo, podemos destacar quatro grandes manifestações nesse período. No mês de março, ocorreram dois grandes protestos em várias cidades do país. Uma manifestação foi realizada no dia $13^{4}$, pedindo o impeachment de Dilma Rousseff e outra, em apoio a presidenta, no dia 18 de março ${ }^{5}$. No mês de abril, os manifestantes a favor e contra Dilma Rousseff se reuniram mais uma vez para acompanhar a votação da admissibilidade do impeachment na Câmara dos Deputados ${ }^{6}$. Em

\footnotetext{
${ }^{3}$ Disponível em https://acervo.estadao.com.br/noticias/acervo,cronologia-protestos-2015-a-2016,12157,0.htm. Acesso em 16 dez. 2020.

${ }^{4}$ Disponível em https://brasil.elpais.com/brasil/2016/03/13/politica/1457872702_704608.html. Acesso em 04 de set. 2017.

5 Disponível em https://noticias.uol.com.br/politica/ultimas-noticias/2016/03/18/manifestacoes-progovernoacontecem-em-24-estados-e-distrito-federal.htm. Acesso em 04 de set. 2017.

${ }^{6}$ Disponível em http://g1.globo.com/politica/processo-de-impeachment-dedilma/noticia/2016/04/manifestacoesfavor-do-impeachment-ocorrem-neste-domingo.html. Acesso em 04 de set. 2017.
} 
maio, quando o pedido de impeachment foi votado no Senado, manifestantes a favor da presidenta se reuniram para protestar ${ }^{7}$.

Os protestos foram organizados nas mídias sociais por meios de eventos no Facebook, publicações, tweets, vídeos entre outros. Grupos a favor do impeachment, como o Movimento Brasil Livre, Vem Pra Rua e Nas Ruas se concentravam em produzir conteúdos com críticas ao governo e ao partido da presidenta, reforçando a ideia de que o impeachment era necessário e melhor para o país. Já os grupos contrários ao impeachment, como a Frente Brasil Popular, Frente Povo Sem Medo e Mídia Ninja produziam conteúdos focando na ideia de que o impeachment era ilegítimo e que se tratava de um golpe à democracia.

Ficou claro que vários grupos políticos utilizaram as mídias sociais como ferramenta importante para mobilizar suas ideias em prol da saída ou permanência da presidenta. O próprio MBL, fundado em 2014, considerava o Facebook como ferramenta fundamental. A importância do Facebook consta no "Manual de instruções para filiais municipais" do movimento, com algumas diretrizes de como utilizar as páginas do movimento em cidades. $\mathrm{O}$ MBL considera a página do Facebook uma importante forma de se divulgar das ideias do movimento com o compartilhamento de textos e imagens. Além disso, a mídia social também era indicada para espaço de debates, cursos entre outras atividades (Barbosa, 2017). O Facebook, então, além de ferramenta de informação, se tornaria um espaço de articulação e formação dos militantes e apoiadores do grupo.

Já a Frente Brasil Popular, que reúne uma gama de movimentos sociais, não cita diretamente a atuação do movimento no Facebook na sua cartilha de documentos básicos, pois destaca que a estrutura organizativa deve levar em conta as especificidades dos movimentos que compõem a frente. No entanto, o documento ressalta a importância de se construir um trabalho conjunto entre os meios de comunicação, levando em conta o trabalho de ativistas, blogueiros e jornalistas livres. Além disso, o documento reforça a necessidade de articular os meios de comunicação, principalmente os populares, para enfrentar a ideologia da direita.

\section{Metodologia}

A partir da discussão acima, buscou-se analisar as estratégias de comunicação e de uso de affordances utilizadas pelas vanguardas digitais (Gerbaudo, 2016) das páginas do

\footnotetext{
7 Disponível em http://www1.folha.uol.com.br/poder/2016/05/1769911-manifestacoes-durante-votacaono-
} senado-devem-ter-menor-adesao.shtml. Acesso em 04 de set. 2017. 
Facebook da Frente Brasil Popular e pelo Movimento Brasil Livre entre março e abril de 2016, período pré-impeachment da Presidenta Dilma Rousseff.

Para este trabalho, foram escolhidos dois grupos importantes nas articulações dos protestos que ocorreram em março e abril de 2016. O primeiro se localiza à esquerda no espectro ideológico, a Frente Brasil Popular, frente organizada por movimentos sociais como Movimentos dos Trabalhadores Sem-Terra (MST), União Nacional dos Estudantes (UNE), Central Única dos Trabalhadores (CUT), entre outras ${ }^{8}$. A segunda página se localiza à direita no espectro ideológico, o Movimento Brasil Livre, grupo criado em 2014 e que tem como forte pauta a defesa do liberalismo econômico, mas também o conservadorismo no campo dos costumes.

A mídia social escolhida para este trabalho foi o Facebook, exatamente por ser a mídia mais usada no Brasil naquele período ${ }^{9}$. Os dados foram capturados com o aplicativo Netvizz durante o ano de $2016^{10}$. O recorte de observação escolhido foram os meses de março e abril de 2016. O período escolhido se justifica por ser um momento específico da tramitação do Congresso, cerca de 40 dias antes da votação pela admissibilidade do impeachment pelos deputados federais (17 de abril). Sabe-se que o período de tramitação no Congresso até a votação no Senado que decidiu pela saída definitiva da presidenta durou meses. No entanto, optou-se por esse período por ter sido marcado por um debate público mais intenso e por grandes manifestações de rua entre os apoiadores da presidenta e apoiadores do impeachment até o dia 17 de abril. Entende-se que, dessa forma, se trata de um momento de grande atividade desses dois grupos de vanguardas digitais.

A fim de fazer uma análise aprofundada, optou-se por um recorte das 150 postagens com maior engajamento. Acredita-se que as postagens com maior engajamento podem ser materiais ricos de informações, sobressaltando as estratégias mais recorrentes e mais bem sucedidas de cada grupo.

A tipologia de classificação construída para a análise de conteúdo das postagens das páginas no período pré-impeachment da Presidenta Dilma Rousseff foi definida dessa forma:

1) Tipo de mídia da postagem: a) foto; b) vídeo; c) link; d) evento.

2) Link para a postagem

3) Engajamento na postagem

\footnotetext{
${ }^{8}$ Disponível em http://frentebrasilpopular.org.br/conteudo/organizacoes-participantes/. Acesso em 12 ago. 2019.

9 Disponível em https://www.statista.com/statistics/268136/top-15-countries-based-on-number-of-facebookusers/. Acesso em 12 ago. 2019.

${ }^{10}$ Agradecemos a contribuição de Tayrine Dias ao disponibilizar os dados coletados pelo Netvizz para esta pesquisa.
} 
4) Mensagem da postagem

5) Assunto: Os assuntos principais abordados nas postagens foram descritos com palavras-chave.

6) Fonte: A fonte de informação originária da notícia

7) Conteúdo: Foi classificado pelas categorias a) informativo - Conteúdo com informações; b) argumentativo - Conteúdo que se esforçava para construir um argumento contrário ou a favor de determinada questão; c) convocação e publicização de protestos offline; d) convocação e publicização de protestos online. Essas categorias podem ser sobrepostas.

8) Postagem se referia à Presidenta Dilma Rousseff de alguma forma (governo ou pessoalmente): a) sim; b) não.

9) Postagem pedia por doações ou participações: a) sim; b) não.

Será possível observar dentro das análises feitas neste trabalho uma mescla de métodos, sendo usadas: análises de conteúdo e análises estatísticas.

\section{Análise dos dados}

As análises comparativas entre a Frente Brasil Popular e o Movimento Brasil Livre apresentadas neste subtópico seguem a sequência abaixo. Salienta-se que a finalidade da construção do corpo de análises aqui apresentado foi fazer um primeiro mapeamento comparativo das estratégias de usos das affordances disponíveis na mídia social Facebook pelos dois grupos aqui pesquisados.

As análises levaram em conta as seguintes categorias:

1) Postagens feitas - Comparou-se o número de postagens com o objetivo de se entender o investimento dos grupos em presença na rede;

2) Engajamento nas postagens - Comparou-se o engajamento dos seguidores das páginas com o objetivo de se entender o quanto as páginas têm comunidades participativas;

3) Tipo de conteúdo postado - Compararam-se os tipos de conteúdo postados com o objetivo de se entender as estratégias das páginas no momento pré-impeachment;

4) Assuntos abordados - Compararam-se os assuntos abordados com o objetivo de se entender por onde passou a argumentação das páginas no momento pré-impeachment; 
5) Postagens com referência à Presidenta Dilma - Comparou-se nesta análise o quanto as páginas se dedicaram, direta ou indiretamente, a falar da Presidenta Dilma Rousseff com o objetivo de se entender a centralidade deste assunto para as páginas;

6) Uso de hashtags - Comparou-se se o uso de hashtags com o objetivo de se entender se esta foi uma estratégia usada no momento pré-impeachment;

7) Fontes de conteúdo usadas pela página - Comparou-se o uso das fontes dos conteúdos das postagens com o objetivo de se entender as fontes que muniram as páginas com os argumentos usados;

8) Tipo de mídias usadas nas postagens - Compararam-se os tipos de mídias usadas nas postagens com o objetivo de se entender a qual estratégia comunicativa as páginas recorreram;

9) Convites para a doação e participação no movimento - Comparou-se se havia convites para doação ou para doação de fundos para o movimento com o objetivo de se entender se o movimento esteve investindo na criação de uma comunidade participativa e apoiadora.

No período recortado pelo trabalho, março e abril de 2016, pôde-se observar uma diferença comparativa consistente no uso das affordances disponíveis pelo Facebook.

Primeiramente, se vê uma ampla diferença entre os números das postagens quando comparados o Movimento Brasil Livre e a Frente Brasil Popular. O Movimento Brasil Livre (2698 postagens) postou três vezes mais que a Frente Brasil Popular (819 postagens) no período de um mês. Isso demonstra que o MBL se utiliza do quantitativo de postagens para tentar marcar uma presença massiva na timeline dos seguidores para movimentar suas redes.

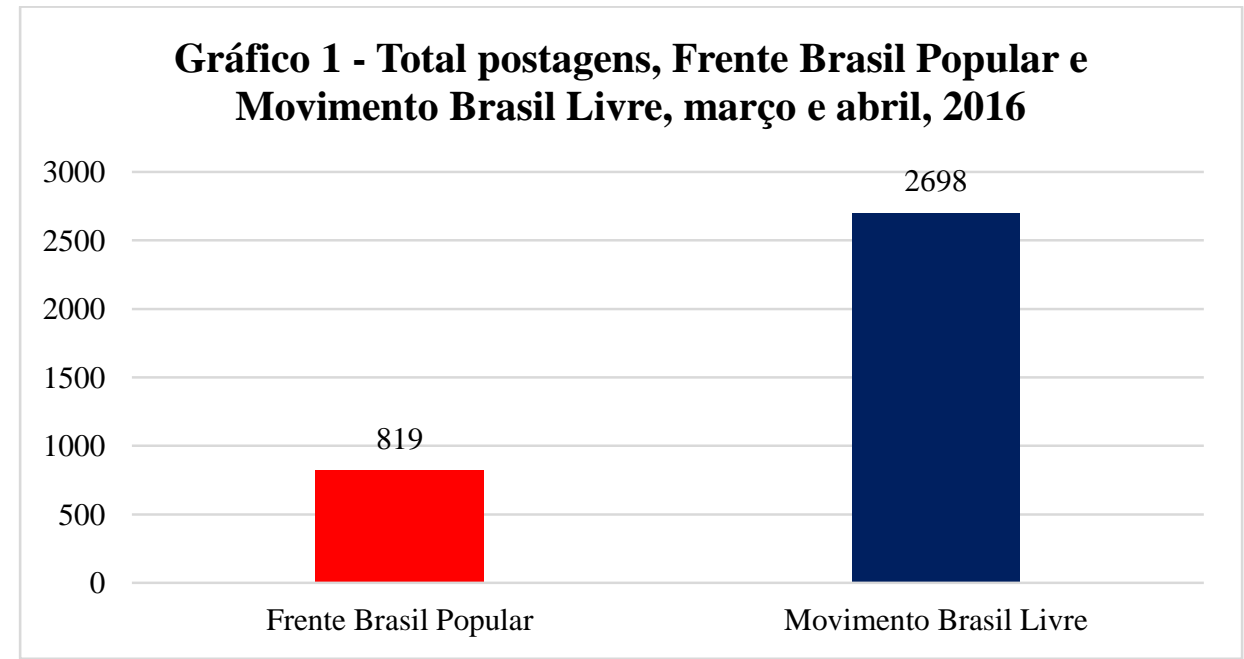

Fonte: Elaboração própria. 
Dando continuidade às análises de dados, focou-se o olhar, a partir desse ponto, nas 150 postagens com maior engajamento entre os dois grupos, entendendo que o engajamento é uma métrica em que se leva em consideração a soma de todas as interações que a postagem obteve (curtidas, comentários e compartilhamentos). Como foi dito, a escolha por analisar postagens com maior engajamento foi feita por ser necessário um recorte. Acredita-se que as postagens com maior engajamento possam ser representativas do perfil dessas páginas, uma vez que um maior engajamento tende a indicar a estratégia desenvolvida pelo grupo, que é o objetivo desta análise.

Nota-se que o engajamento médio do Movimento Brasil Livre, 82.719,0, é sessenta e seis vezes maior que o engajamento médio da Frente Brasil Popular, 1.245,9. Essa diferença de engajamento pode ter a ver com o número superior de curtidas na página do Movimento Brasil Livre, 3.436.614 ${ }^{11}$ em relação ao número de curtidas na página da Frente Brasil Livre, $160.724^{12}$, mas também com o tipo de conteúdo que foi postado pela página, como será visto mais adiante.

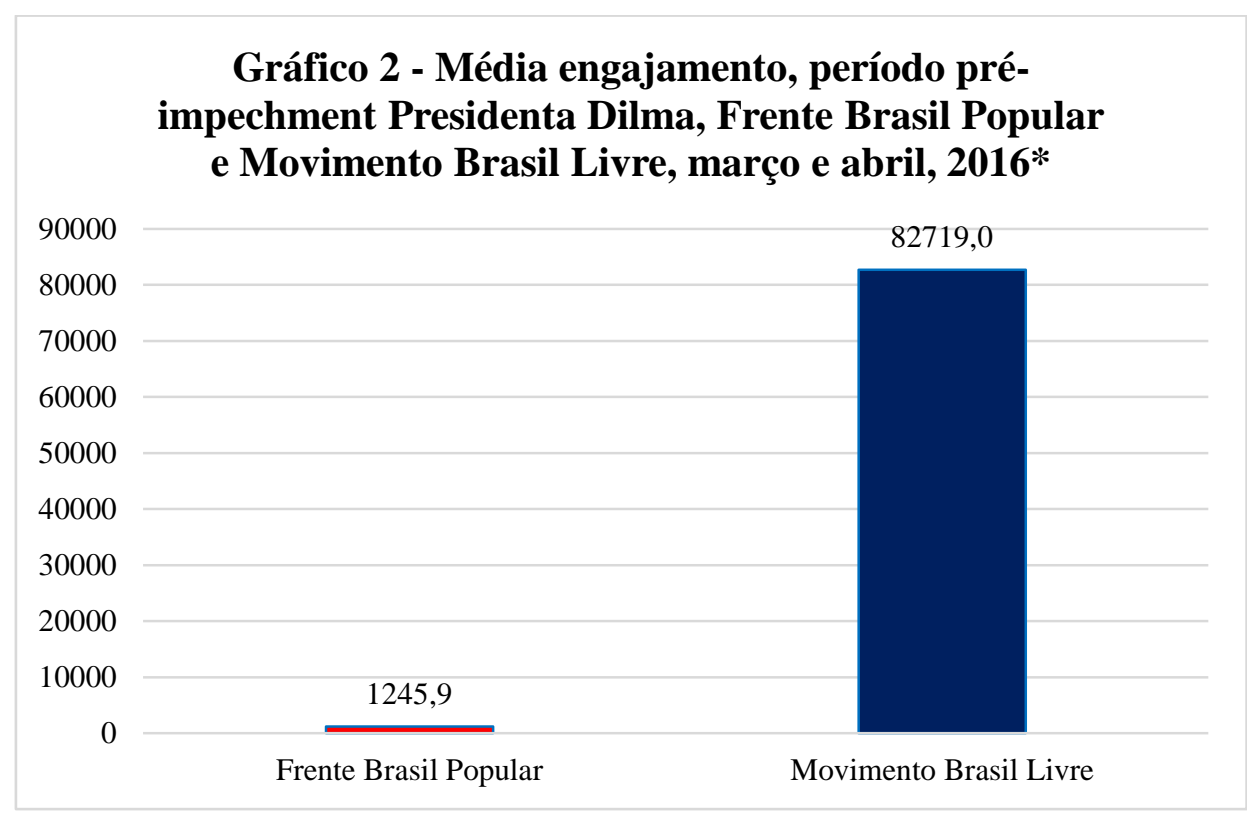

Fonte: Elaboração própria.

*Dados das 150 postagens com maior engajamento do mês de março de 2016.

Diante de realidades completamente díspares em relação ao engajamento das comunidades das duas páginas, será feita a seguir a análise das 150 postagens com maior engajamento.

\footnotetext{
${ }^{11}$ Dados de agosto de 2019.

${ }^{12}$ Dados de agosto de 2019.
} 
Por meio da análise de conteúdo das postagens, também foi possível classificar se se tratavam de postagens informativas, argumentativas, relativas a protestos offline ou a protestos online $^{13}$. E mais uma vez houve uma grande diferença no modo de atuação do Movimento Brasil Livre e da Frente Brasil Popular. Em março e abril de 2016, a Frente Brasil popular teve em suas respectivas postagens com maior engajamento, convocações ou publicizações de protestos offline, assim 70,0\% das postagens se enquadraram nessa categoria, como foi o caso da postagem abaixo (Figura 1).

Figura 1 - Postagem de tipo "Convocação e publicização de protestos offline”, Frente Brasil Popular, 2016
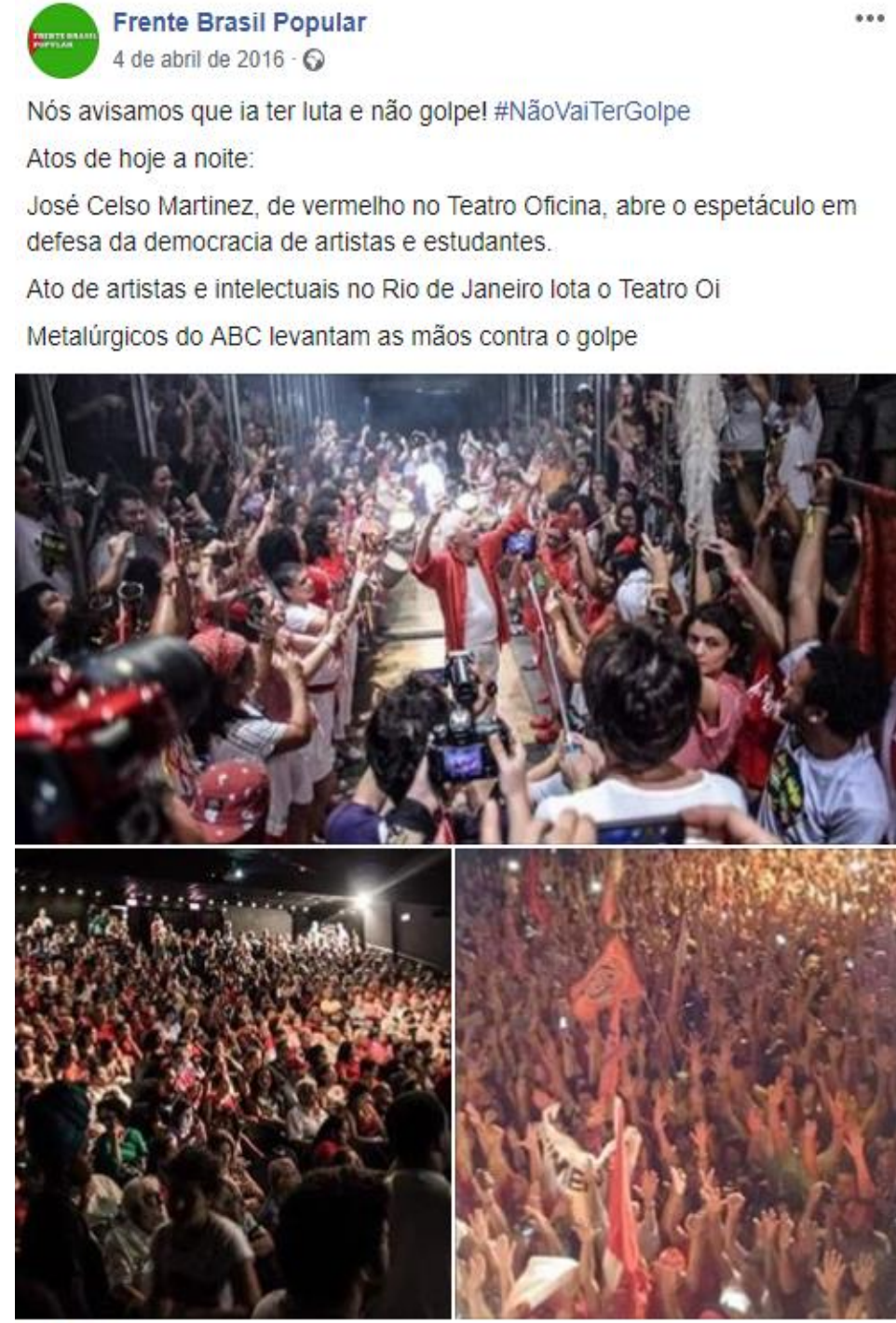

Fonte: Página do Facebook "Frente Brasil Popular".

\footnotetext{
${ }^{13}$ As categorias não são excludentes, portanto, pode haver postagens que se classificam em duas ou mais categorias.
} 
O segundo tipo de postagens foram as informativas, 29,3\%; em terceiro lugar estão as postagens argumentativas, 6,0\%; e por fim, com 2,0\%, estão as postagens que tratavam de mobilizações online. Fica clara, portanto, a centralidade das mobilizações nas ruas no período pré-votação do impeachment da Presidenta Dilma Rousseff na página Frente Brasil Popular.

Já no caso do Movimento Brasil Livre, a preocupação central da página do Facebook foi informar sobre questões políticas, 87,3\%. Essas postagens costuraram uma polarização do debate no sentido de uma marcação bem sublinhada de um "nós" e "eles", identificando indivíduos e instituições a serem seguidos e outros a serem execrados. Além disso, a defesa do impeachment foi feita repetidamente no recorte de tempo, como foi o caso da postagem abaixo (Figura 2):

Figura 2 - Postagem de tipo "Informativa", Movimento Brasil Livre, 2016

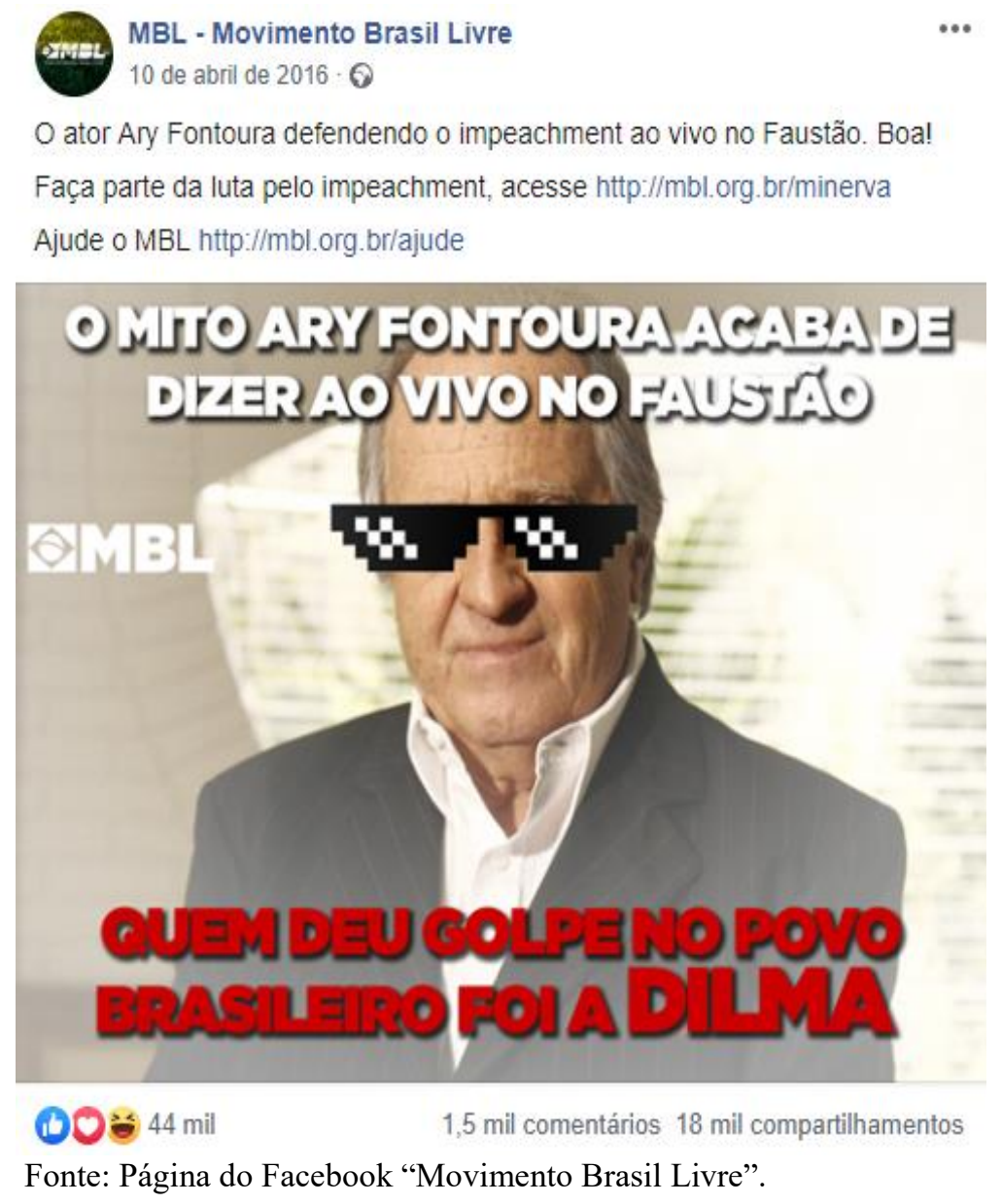

Em segundo lugar, com uma porcentagem muito abaixo das postagens informativas, aparecem "protestos offline", com 18,7\% do recorte de postagens se enquadrando nessa tipologia. O MBL se preocupou que um quinto de suas postagens também remetesse a convocação de protestos de rua ou na publicização desses protestos, e não houve menção a 
protestos online. Inclusive, a postagem com o maior engajamento da página do MBL no período pesquisado se enquadra nessa tipologia e se trata de um vídeo de um protesto a favor do impeachment de Dilma Rousseff na Avenida Paulista na cidade de São Paulo (Figura 3).

\section{Figura 3 - Postagem do tipo "Protestos Offline", Movimento Brasil Livre, 2016 \\ MBL - Movimento Brasil Livre · Seguir \\ 16 de março de 2016 - 9 \\ PAULISTA AGORA CHEIA PELO FIM DO GOVERNO PETISTA! FORA LULA! FORA DILMA!}

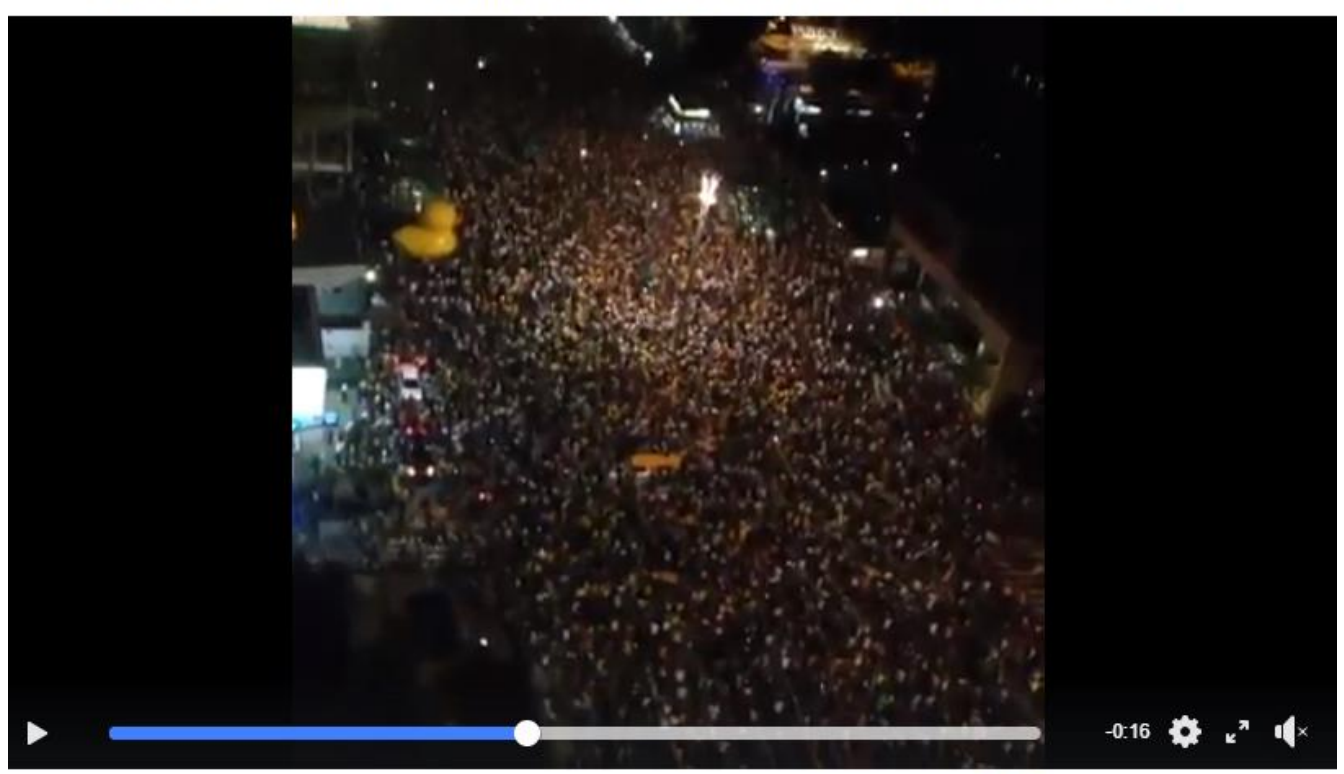

$\triangle$ Curtir $\square$ Comentar $\Leftrightarrow$ Compartilhar

$00 \% 60$ mil - 3,4 mil comentários

Fonte: Página do Facebook "Movimento Brasil Livre”.

Em terceiro lugar, com 17,3\%, apareceram as postagens de conteúdo argumentativo, sendo que essas se focaram em debater a necessidade do impeachment e problemas relacionados ao Partido dos Trabalhadores. Ou seja, no pequeno conteúdo argumentativo produzido, parece que o MBL esteve focado em produzir conteúdos que reforçassem a ideia de que o Partido dos Trabalhadores e os políticos do partido estariam ligados à corrupção. $\mathrm{O}$ foco desse tipo de publicação indicava querer enraizar argumentos e sentimentos a respeito das instituições supracitadas. Além disso, o conteúdo argumentativo é capaz de criar narrativas e mobilizar pessoas. Ao encabeçar uma campanha a favor do impeachment e contra o PT, o MBL estimulava e compartilhava sentimentos entre seus seguidores, como indignação, raiva, ódio e esperança por um Brasil melhor. Essas emoções são fundamentais para ações de protestos políticos (Jasper, 2014). Por fim, dentre as postagens analisadas, nenhuma indicou a convocação ou publicização de protestos online. 
De fato, no Facebook do MBL houve uma baixa porcentagem de postagens relativas à protestos, tanto offline quanto online. É possível que em outras mídias sociais (como o whatsapp) e em outras páginas de grupos favoráveis ao impeachment as convocações para os protestos estivessem mais visíveis. Ainda assim, não foram analisados os eventos criados por essas páginas. Os eventos no Facebook, em geral, convidam para ações face a face.

\section{Gráfico 3 - Percentagem de tipos de conteúdos das postagens, período pré-impechment Presidenta Dilma, Frente Brasil Popular e Movimento Brasil Livre, março e abril, 2016*}

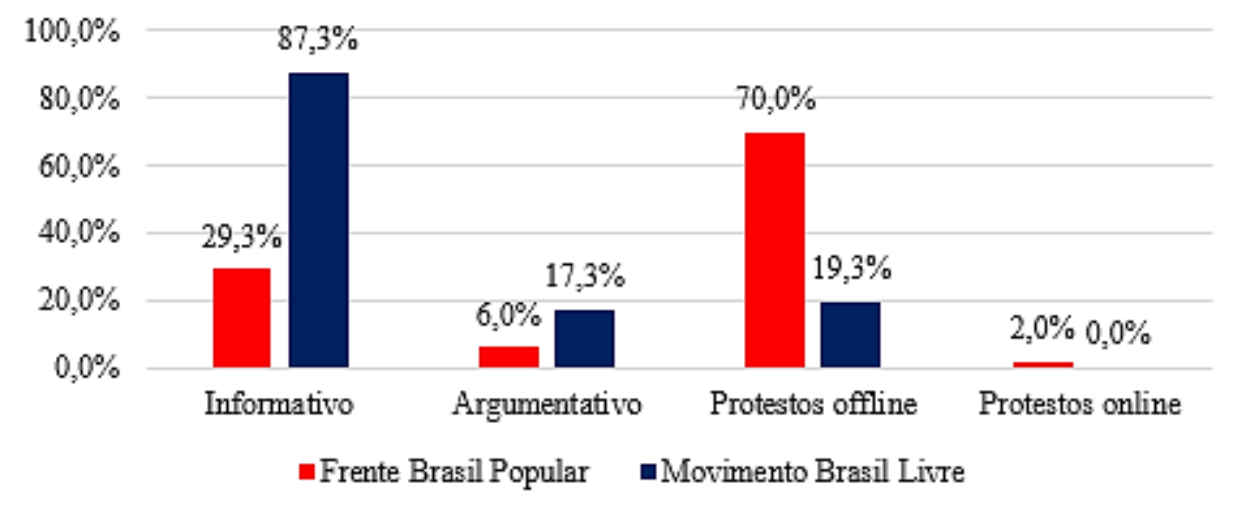

Fonte: Elaboração própria.

*Dados das 150 postagens com maior engajamento do mês de março de 2016.

Indo mais a fundo nos assuntos das postagens, após a análise de conteúdo, definiu-se o assunto principal de cada postagem lida. O diagrama de nuvem de palavras (Figuras 4 e 6) foi construído para que pudesse ser mais fácil a visualização dos assuntos mais escritos.

No caso do Movimento Brasil Livre, como se pode observar na Figura 4, os assuntos mais comentados nas postagens foram o Impeachment, Lula e Dilma. Surpreende-se que Lula esteja em $2^{\circ}$ lugar, já que o momento histórico não tinha a ver diretamente com ele, no entanto, postagens a respeito de sua possível nomeação como ministro e de uma corrupção que o circundaria ficaram salientes. A estratégia do MBL indica que se aproveitaram daquele momento histórico para desconstruir também o adversário político Lula, uma das maiores lideranças de esquerda do país. 
Figura 4 - Nuvem de assuntos tratados pelo MBL, março e abril, 2016*

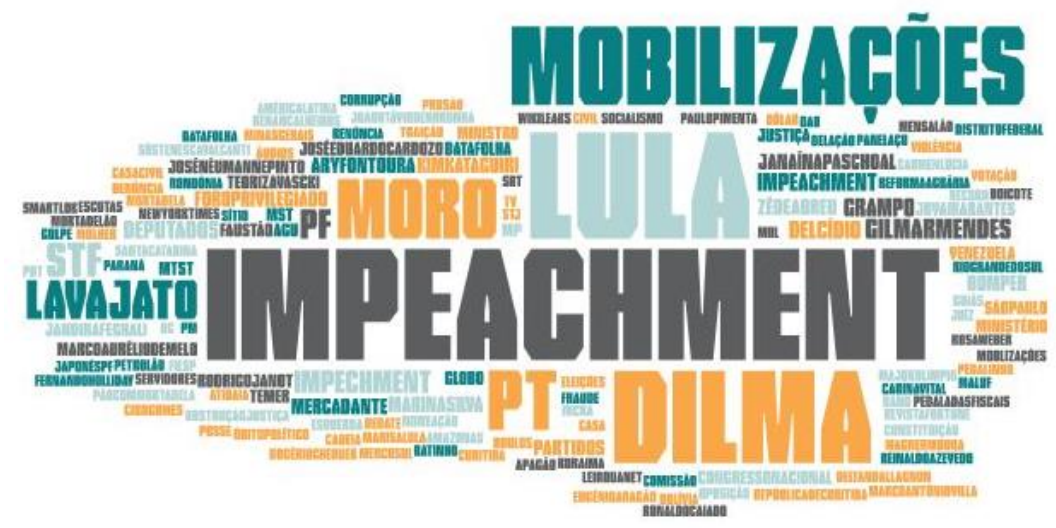

Fonte: Elaboração própria.

*Dados das 150 postagens com maior engajamento do mês de março de 2016.

Também é possível notar outros assuntos centrais como: Mobilizações, Moro, PT, Lava Jato e PF. A nuvem de palavras do Movimento Brasil Livre mostra que o grupo dedicou-se, em março de 2016, a fazer oposição ao governo. Mesmo quando citam positivamente o Juiz Sérgio Moro e da Operação Lava Jato (ver figura 5), esses subtópicos estão ligados ao "combate" que tais atores fazem à Dilma Rousseff, Lula, PT e outras figuras circundantes.

Figura 5 - Postagem sobre Sérgio Moro, Movimento Brasil Livre, 2016

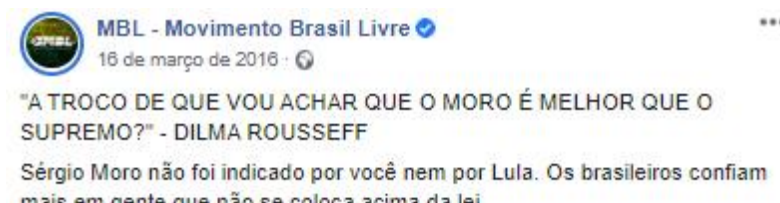
mais em gente que não se coloca acima da lei.

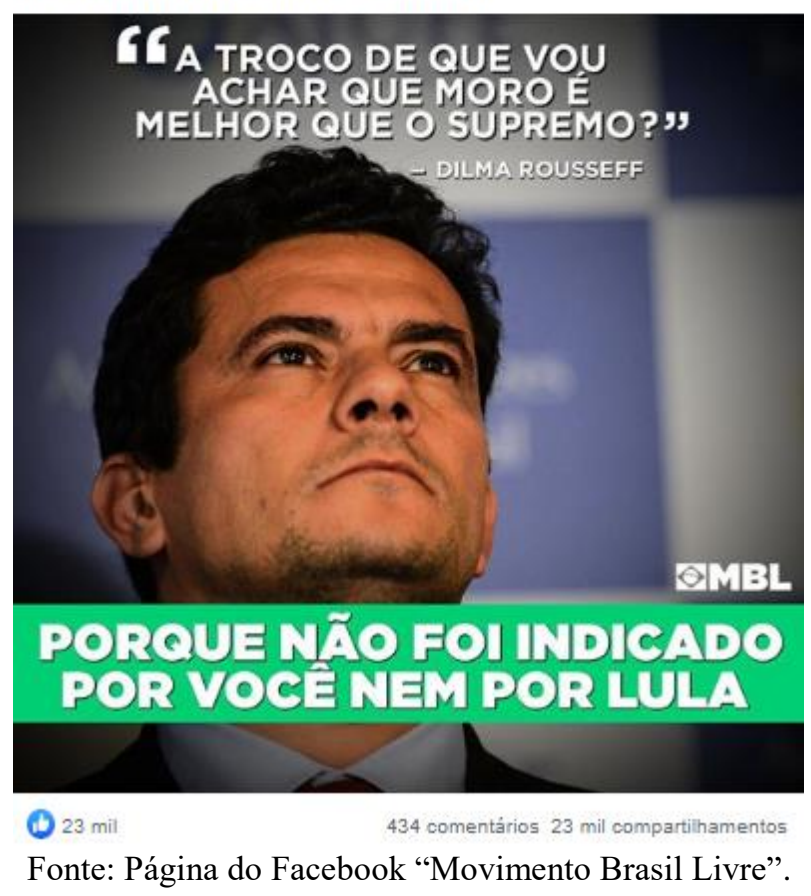


O foco do Movimento Brasil Livre no Facebook encaminhou-se no sentido de fortalecer o antipetismo e os argumentos de rejeição às figuras ligadas ao PT, sendo as mobilizações só uma parte de uma construção retórica mais ampla.

Corroborando o demonstrado no Gráfico 3, a agenda de assuntos da Frente Brasil Popular no período pré-votação do impeachment da Presidenta Dilma Rousseff teve como assunto primordial a convocação e publicização de mobilizações. Outros assuntos também trazidos para o centro do debate foram: Golpe; Democracia, Dilma.

É interessante notar que, quando se compara a Figura 4 à Figura 6, alguns assuntos são mobilizados somente por um dos grupos. Enquanto o Movimento Brasil Livre usou o assunto "impeachment", as postagens da Frente Brasil Popular usaram o assunto "golpe" e o assunto "democracia". Em contrapartida, o Movimento Brasil Livre personalizou o debate e utilizou diretamente o assunto "Dilma", "Lula" e "Moro" em grande medida.

Figura 6 - Nuvem de assuntos tratados pela Frente Brasil Popular, março e abril, 2016*

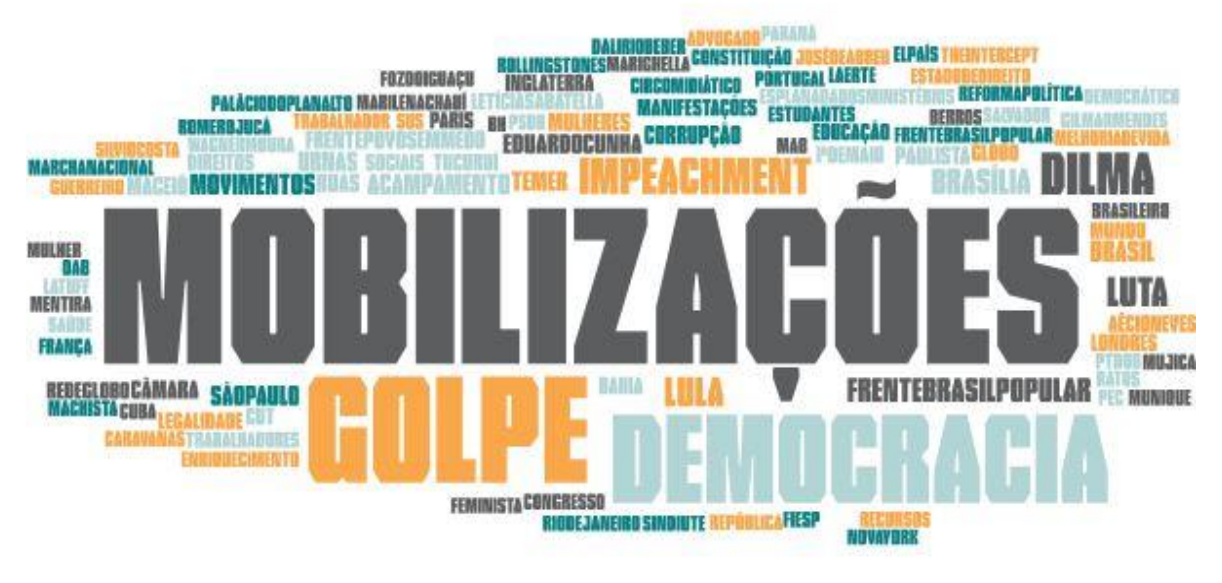

Fonte: Elaboração própria.

*Dados das 150 postagens com maior engajamento do mês de março de 2016.

No gráfico abaixo, pode-se notar que a maioria das postagens de ambos os grupos abordaram diretamente ou indiretamente a Presidenta Dilma Rousseff. Entende-se por postagem direta aquela que cita a Presidenta ou o Governo Dilma Rousseff. Já a postagem indireta entende-se aquela que cita mobilizações ou assuntos sobre o Governo Dilma Rousseff, mas não citam o nome da Presidenta diretamente. 
Na página da Frente Brasil Popular foram 94,0\% das postagens e na página do Movimento Brasil Livre foram 78,0\% das postagens.

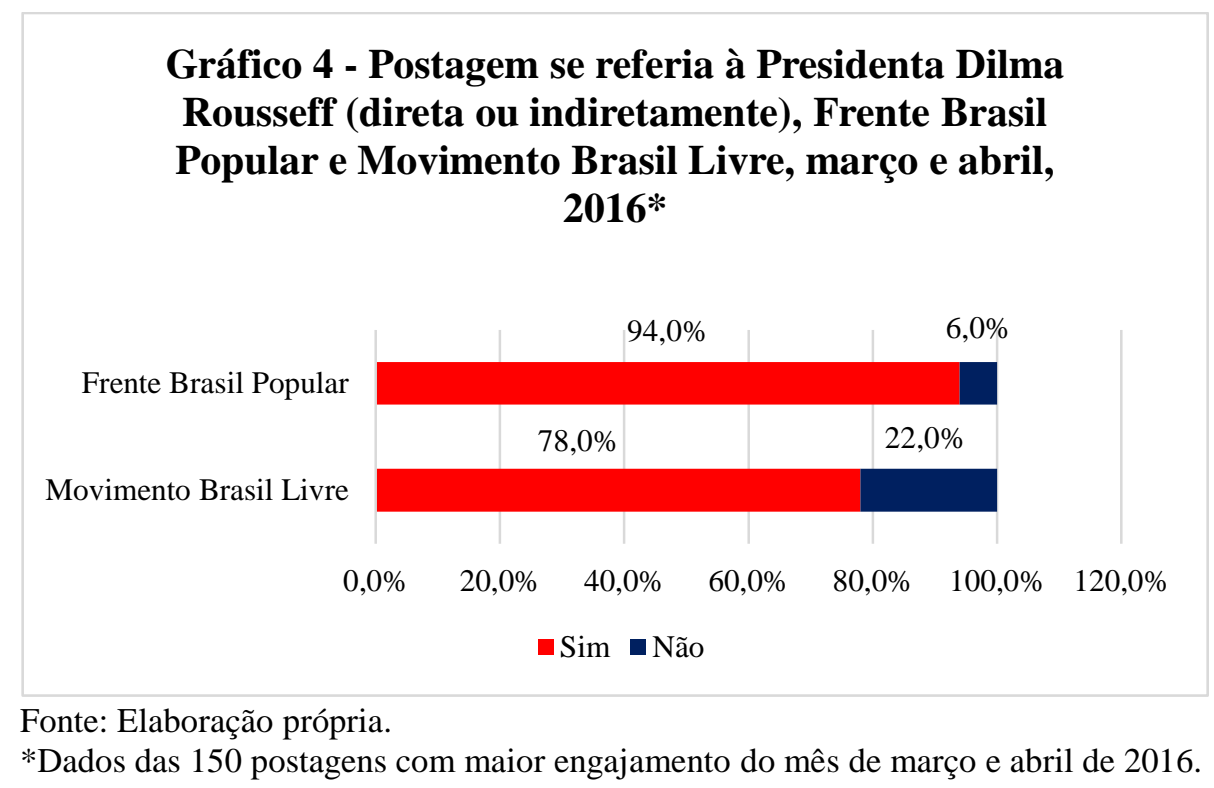

Sobre o uso de hashtags em mídias sociais, pode-se dizer que têm sido empregadas pelos usuários para classificar postagens dentro de grupos de assuntos e facilitar sua visibilidade para a comunidade da mídia social que esteja procurando mais sobre aquela temática. Neste tópico, mais uma vez vemos diferenças de utilização das affordances disponíveis no Facebook pelos grupos, o Movimento Brasil Livre usou hashtag em apenas uma postagem, esta foi \#Mortadeladay em postagem sobre manifestações "petistas" (Figura 7). 


\section{Figura 7 - Postagem com a única hashtag usada pelo Movimento Brasil Livre,} \#MortadelaDay*

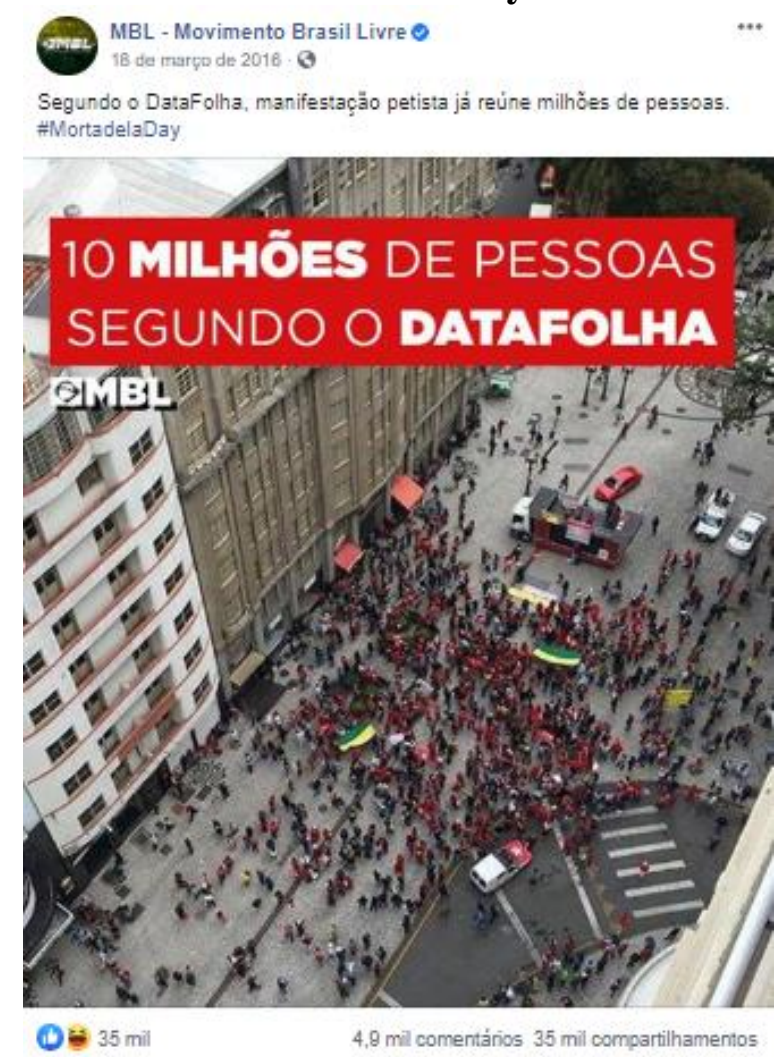

Fonte: Página do Facebook "Movimento Brasil Livre" *Dados das 150 postagens com maior engajamento do mês de março e abril de 2016.

Já a Frente Brasil Popular utilizou hashtags em um número expressivo de postagens, $42,0 \%$.

\section{Gráfico 5 - Uso de hashtags, Frente Brasil Popular e Movimento Brasil Livre, março e abril, 2016*}

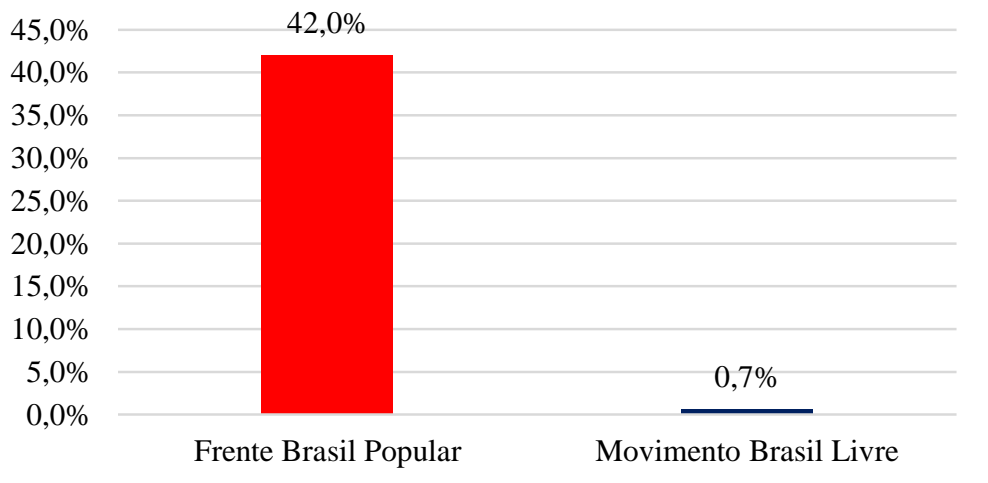

Fonte: Elaboração própria.

*Dados das 150 postagens com maior engajamento do mês de março de 2016. 
Indo mais a fundo e analisando as hashtags usadas pela Frente Brasil Popular, as mais vistas foram \#vempraDemoracia, \#vemprademocracia, \#brasilcontraogolpe, \#nãovaitergolpe, \#vaiterluta, \#respeiteasurnas, \#dilmaficagolpesai.

Sabe-se que as hashtags são bastante utilizadas para amplificar conteúdos nas mídias sociais como Instagram e Twitter. No entanto, no Facebook elas limitam o alcance das publicações. Essa affordance, então, não parece ser útil para essa mídia social e o MBL soube que não deveria utilizá-la.

\section{Figura 8 - Nuvem de hashtags usadas Frente Brasil Popular, março e abril, 2016*}

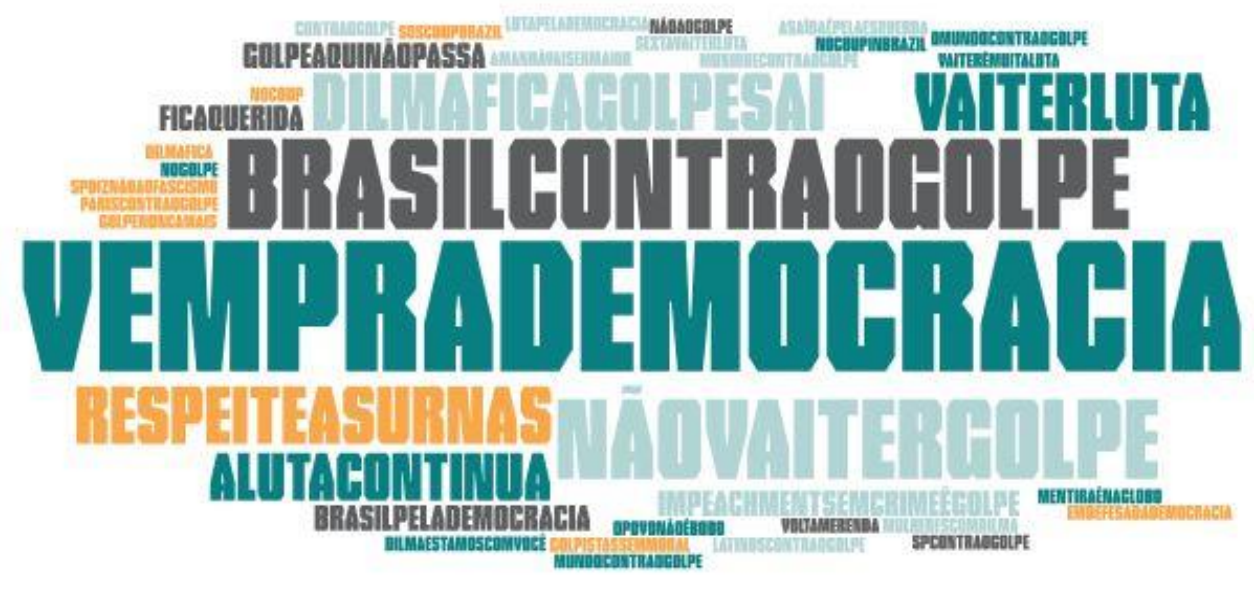

Fonte: Elaboração própria.

*Dados das 150 postagens com maior engajamento do mês de março de 2016.

A partir da análise das fontes usadas como base para as postagens, percebe-se aqui uma mesma estratégia referente ao uso de fontes pelo Movimento Brasil Livre e a pela Frente Brasil Popular, isso porque ambos usam a si próprios como fontes para publicações na maioria dos casos.

No caso do Movimento Brasil Livre, 85,3\% das postagens tiveram como fonte o próprio Movimento Brasil Livre. As demais, 14,7\%, dividiram-se entre as seguintes fontes, Rede Globo (6\%), a Revista Veja (2,7\%), Jornal Folha de São Paulo e TV Cultura (1,3\%, e Coluna Esplanada, Estadão, Oposição Zueira, Reacionaria e STF com 0,7\% das postagens cada.

Já as fontes usadas para postagens da Frente Brasil Popular são em maioria estatística do próprio movimento, 70,7\% das postagens. Em segundo lugar está a Mídia Ninja, usada como base de 10,0\% das postagens. Além disso, outras 18 fontes aparecem. 
O uso prioritário de fontes próprias para as postagens nas páginas do Facebook demonstra a preocupação que o Movimento Brasil Livre e a Frente Brasil Popular tiveram em se estabelecerem como os gatekeepers da narrativa do momento histórico pré-impeachment da presidenta Dilma Rousseff.

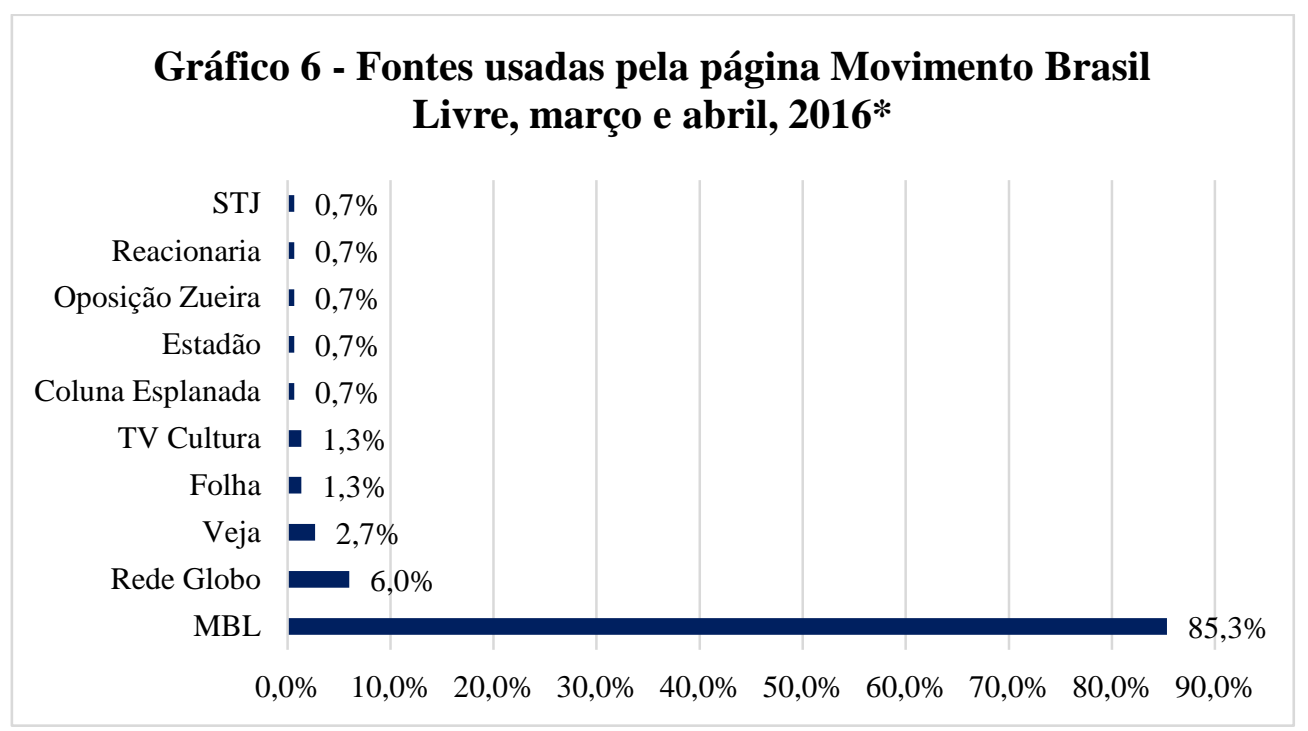

Fonte: Elaboração própria.

*Dados das 150 postagens com maior engajamento do mês de março e abril de 2016.

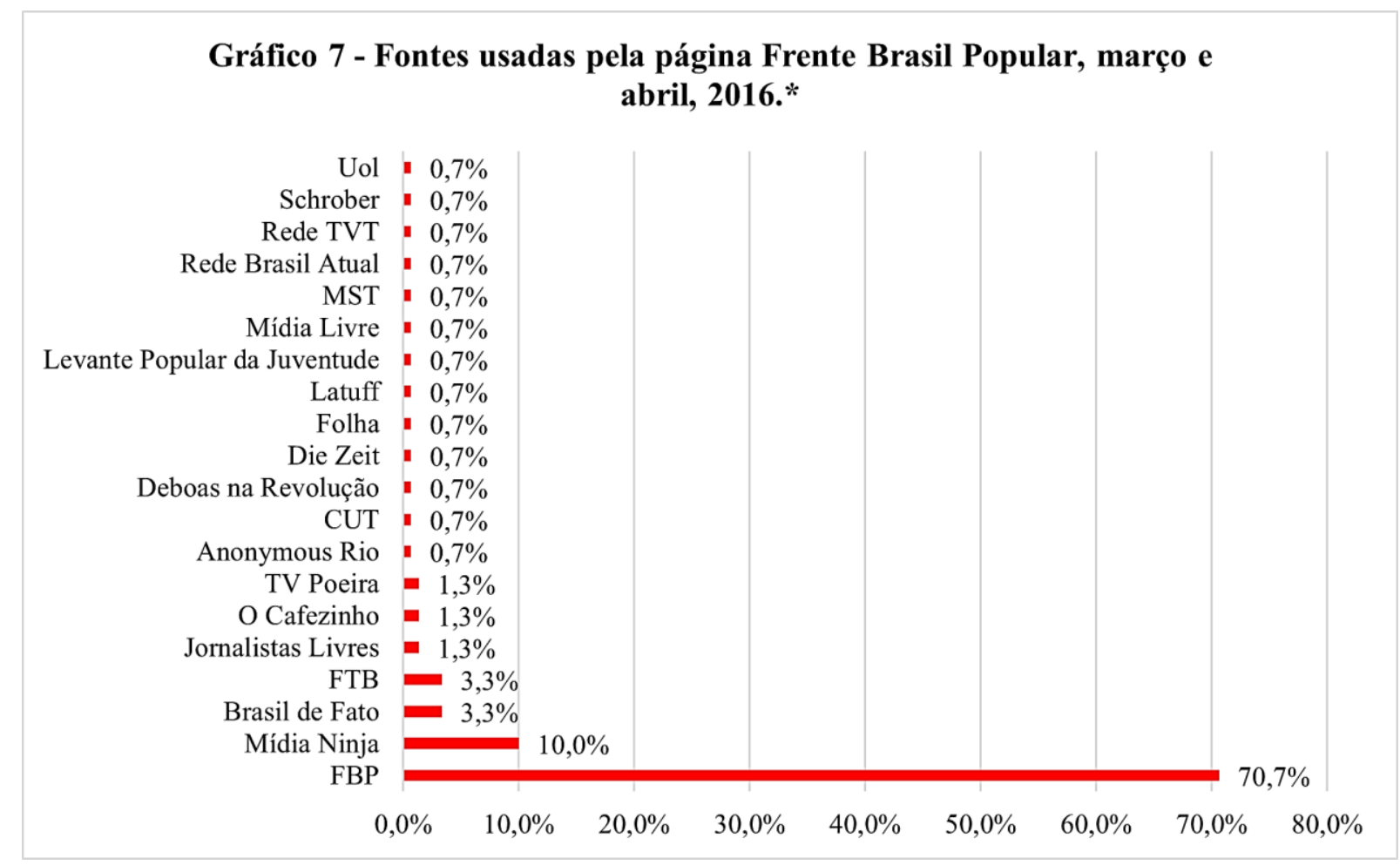

Fonte: Elaboração própria.

*Dados das 150 postagens com maior engajamento do mês de março e abril de 2016. 
Há, ainda, diferenças consistentes no tipo de mídia compartilhada nas postagens das duas páginas. O Movimento Brasil Livre compartilhou fotos em $84 \%$ das postagens, vídeos em 14,7\% e links em 1,3\%. Já a Frente Brasil Popular utilizou-se de uma diversidade maior de possibilidades, compartilhou fotos em 59,3\% das postagens, links em 19,3\% das postagens, vídeos em $16,7 \%$ das postagens e eventos em $4,7 \%$ das postagens.

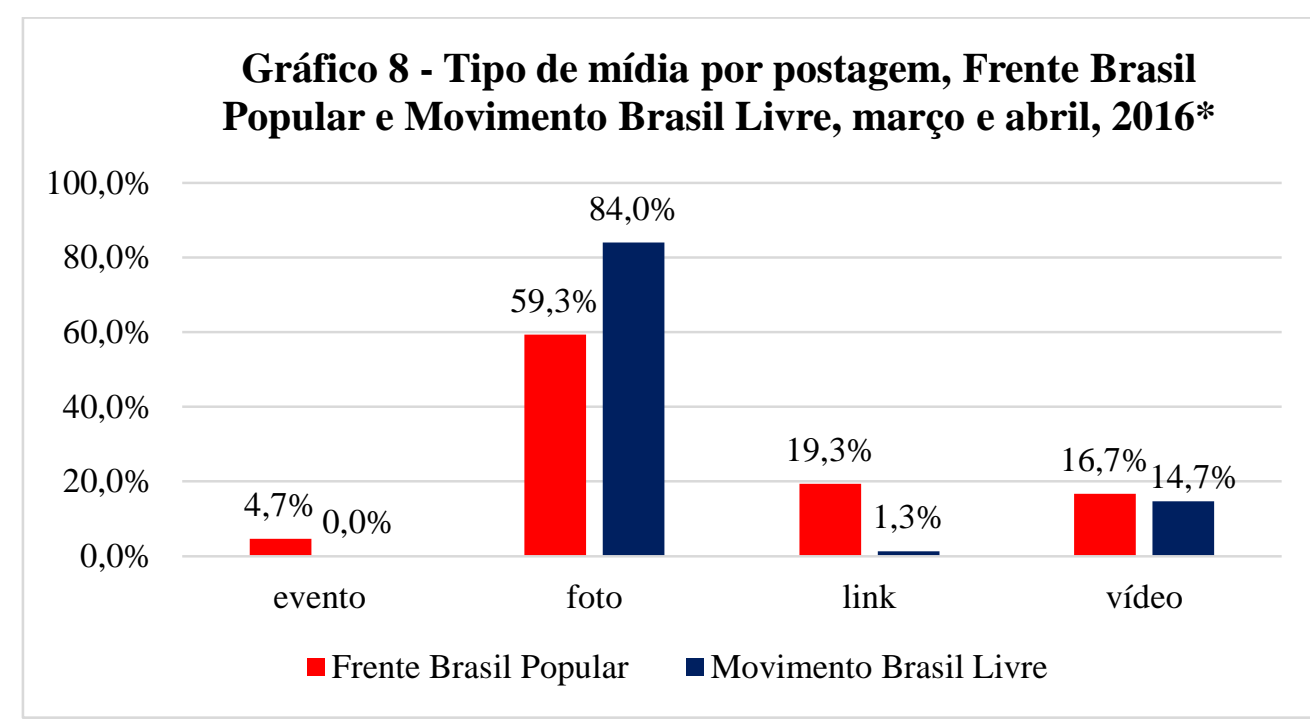

Fonte: Elaboração própria.

*Dados das 150 postagens com maior engajamento do mês de março de 2016.

Por fim, percebe-se que o Movimento Brasil Livre se aproveita do engajamento de seus seguidores para convocá-los para se inscrever oficialmente no movimento e fazerem doações. Em 22,0\% das postagens o Movimento Brasil Livre fez apelos nesse sentido. Isso demonstra o esforço do MBL de criar uma comunidade a partir da página e ainda vínculos de solidariedade com o Movimento. 


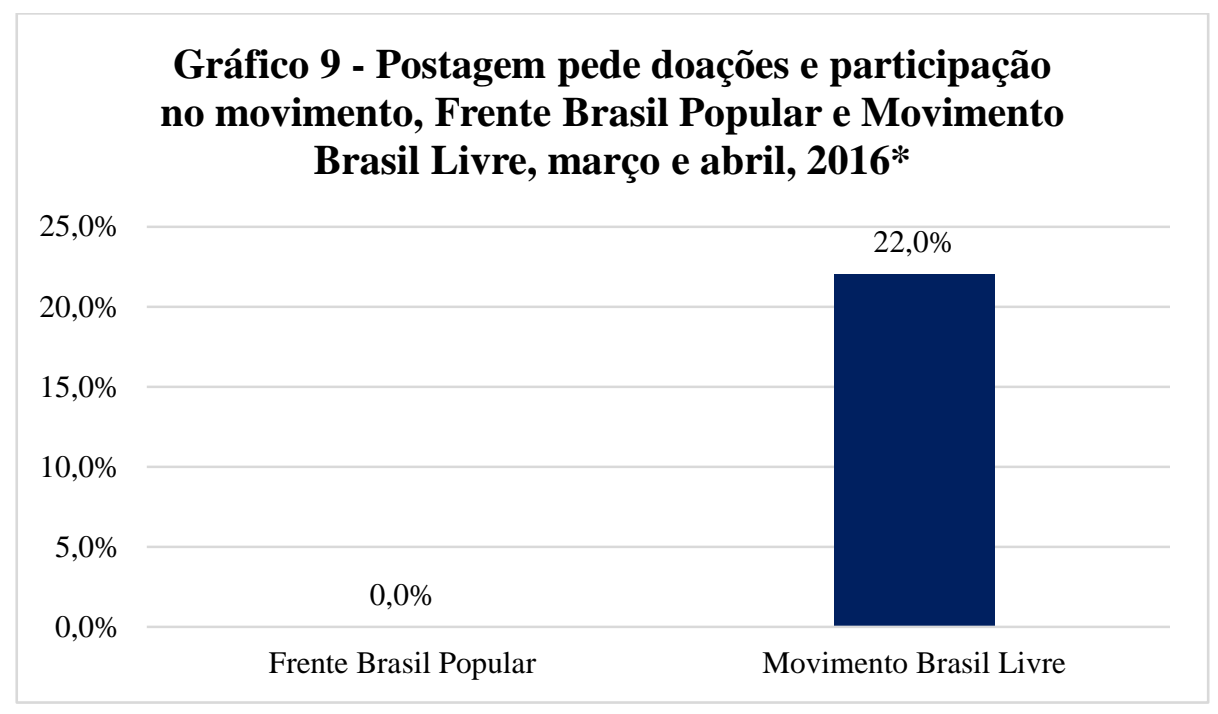

Fonte: Elaboração própria.

*Dados das 150 postagens com maior engajamento do mês de março de 2016.

\section{Considerações Finais}

A análise feita neste trabalho indica-nos que houve estratégias distintas na produção de conteúdo das páginas analisadas. A Tabela 1 abaixo resume as estratégias de uso de affordances usadas pelo pela Frente Brasil Popular e pelo Movimento Brasil Livre entre março e abril de 2016, período pré-impeachment da Presidenta Dilma Rousseff e com grande número de mobilizações online e offline.

A Frente Brasil Popular preocupou-se em centralizar as postagens na convocação e publicização de protestos na rua e se referir à Presidenta e ao Governo Rousseff na maioria robusta de postagens. Também se utilizou de hashtags e usou mídias diversas nos posts. Essa estratégia indica que a finalidade da Frente Brasil Popular em março e abril de 2016 foi, de fato, dar centralidade total ao argumento contrário ao "golpe" e à defesa da democracia através do chamamento e publicização das manifestações de rua.

Já o Movimento Brasil Livre fez um número maior de postagens e também conseguiu um engajamento muito superior em sua página. As postagens do Movimento foram, em sua maioria, informativas e com uma maior heterogeneidade de assuntos abordados. Chama atenção que, além de Dilma, Lula e Moro são assuntos muito abordados. A página não utilizou hashtags, apenas o fez em uma única ocasião, mas utilizou grande uso de fontes da mídia de massa. Além disso, $84 \%$ das postagens foram fotos e houve uma massiva campanha de convite para doações e participação do Movimento. Observando-se o conjunto de variáveis, o Movimento Brasil Livre parece ter aproveitado o momento do pré-impeachment 
para mobilizar as suas redes, menos em relação às manifestações, mas mais em relação a assuntos substanciais centrais em sua agenda. Além disso, fica clara a construção de um discurso que demarcou um "nós" X “eles”, onde o "nós” eram o Moro e a Operação Lava Jato e o "eles" eram Lula, Dilma e o PT.

Tabela 1 - Uso do Facebook no momento pré-impeachment da Presidenta Dilma Rousseff, Movimento Brasil Livre e Frente Brasil Popular, março e abril, 2016

\begin{tabular}{|c|c|c|}
\hline \multirow[b]{2}{*}{ Uso do Facebook } & \multicolumn{2}{|c|}{ Movimentos } \\
\hline & Frente Brasil Popular & $\begin{array}{l}\text { Movimento Brasil } \\
\text { Livre }\end{array}$ \\
\hline Postagens & $\operatorname{Sim}$ & Sim, 3 vezes mais \\
\hline Seguidores engajados* & Sim & 66 vezes mais \\
\hline $\begin{array}{l}\text { Tipo de conteúdo } \\
\text { postado* }\end{array}$ & $\begin{array}{l}\text { Em sua maioria sobre } \\
\text { protestos offline }\end{array}$ & $\begin{array}{l}\text { Em sua maioria } \\
\text { informativo }\end{array}$ \\
\hline $\begin{array}{l}\text { Assuntos mais } \\
\text { abordados nas } \\
\text { postagens* }\end{array}$ & $\begin{array}{c}\text { Impeachment, Lula e } \\
\text { Dilma, Mobilizações, } \\
\text { Moro, PT }\end{array}$ & $\begin{array}{l}\text { Mobilizações, Golpe, } \\
\text { Democracia, Dilma, } \\
\text { Impeachment }\end{array}$ \\
\hline $\begin{array}{l}\text { Se referiu à Dilma } \\
\text { direta ou } \\
\text { indiretamente nas } \\
\text { postagens* }\end{array}$ & Sim, em $94,0 \%$ & Sim, em 78,0\% \\
\hline Uso de hashtags* & $\begin{array}{c}\text { Sim, em } 42,0 \% \text { das } \\
\text { postagens }\end{array}$ & $\begin{array}{c}\text { Sim, } 0,7 \% \text { (penas } 1 \\
\text { postagem) }\end{array}$ \\
\hline $\begin{array}{l}\text { Hashtags mais } \\
\text { usadas* }\end{array}$ & $\begin{array}{l}\text { \#vemprademocracia } \\
\text { \#brasilcontraogolpe } \\
\text { \#nãovaitergolpe } \\
\text { \#vaiterluta } \\
\text { \#respeiteasurnas } \\
\text { \#dilmaficagolpesai }\end{array}$ & \#mortadeladay \\
\hline $\begin{array}{c}\text { Principal fonte usada } \\
\text { pela página* }\end{array}$ & $\begin{array}{c}\text { Ela mesma em } 70,4 \% \\
\text { das postagens }\end{array}$ & $\begin{array}{c}\text { Ela mesma em } 85,3 \% \\
\text { das postagens }\end{array}$ \\
\hline $\begin{array}{l}\text { Tipo de mídia usada } \\
\text { na postagem* }\end{array}$ & $\begin{array}{c}59,3 \% \text { fotos, } 19,3 \% \\
\text { links, } 16,7 \% \text { vídeos, } 4,7 \\
\text { eventos } \%\end{array}$ & $\begin{array}{c}84,0 \% \text { fotos, } 14,7 \% \\
\text { vídeos, } 1,3 \% \text { links }\end{array}$ \\
\hline $\begin{array}{c}\text { Convites para doação } \\
\text { e participação no } \\
\text { movimento* }\end{array}$ & Não & Sim, em $22,0 \%$ \\
\hline
\end{tabular}

Fonte: Elaboração própria.

*Dados das 150 postagens com maior engajamento do mês de março de 2016.

A página da Frente Brasil Popular conseguiu mobilizar bem menos seguidores do que a página do MBL. Isso pode estar relacionado ao número de postagens e também ao tipos de postagens que foram usados nas páginas. Como vimos, a página do MBL utilizou-se principalmente de imagens em suas postagens. Sabe-se que, do ponto de vista estratégico, 
para o Facebook, postagens com imagens alcançam uma maior visualização do que somente postagens com textos. Além disso, a página do MBL não utilizou hashtags nas postagens analisadas, o que facilita a amplificação do seu conteúdo. Isso chama a atenção sobre quem compõe a equipe que gerencia mídias sociais dessas contas. Como Gerbaudo (2016a) aponta, a vanguarda digital é composta por várias pessoas para gerir aquela conta na mídia social. Isso, por sua vez, requer investimentos e recursos e uma equipe qualificada, o que nem sempre é possível em grupos e movimentos sociais.

Esses achados nos trazem questões mais amplas sobre como investimento ou escassez de recursos - humanos e financeiros - podem ser importantes para o êxito ou fracasso de grupos, mesmo na era digital. Em seu estudo sobre as organizações estudantis do Chile, Von Bülow, Vilaça e Abelin (2018) mostram que muitas das diferenças da presença digital de grupos são resultados de assimetria na distribuição de recursos. Da mesma forma, Jen Schradie (2019) mostra como movimentos conservadores têm se popularizado nas mídias sociais. Para a autora, ativismo digital muitas vezes acaba reproduzindo desequilíbrios de poder que já existem. Dessa forma, organizações com mais tempo, dinheiro, pessoal e estrutura são capazes de se beneficiar mais dessas ferramentas.

Aqui não temos elementos para identificar a quantidade de recursos empregados por esses grupos para manter suas vanguardas digitais. Também não foi possível, com os dados analisados, identificar se houve postagens impulsionadas ou monetizadas. Para entendermos isso, seria necessário um estudo mais amplo sobre as estruturas organizacionais estudadas.

No entanto, a análise desses dados contribui não só para entender como têm se dado as mobilizações políticas digitalmente mediadas, mas também, traz-nos elementos que permitem que se enxergue melhor o processo de impeachment de Dilma Rousseff, que culminou na saída da presidenta e, posteriormente, na eleição de um presidente de extrema direita.

\section{Referências}

AVRITZER, Leonardo (2017), "Participation in democratic Brazil: from popular hegemony and innovation to middle-class protest". Opinião Pública, v. 23, n. 1, pp. 43-59 [Consult. 26-09-2020]. Disponível em https://www.scielo.br/pdf/op/v23n1/1807-0191-op-23-1-0043.pdf

BARBOSA, Jefferson R. Movimento Brasil Livre (MBL)" e "Estudantes pela Liberdade (EPL): Ativismo Político, Think Tanks e Protestos da Direita No Brasil Contemporâneo" Trabalho apresentado no $41^{\circ}$ Encontro Anual da Anpocs, Caxambu-MG.

BENNETT, W. Lance and SEGERBERG, Alexandra (2013), The Logic of Connective Action: Digital Media and the personalization of Contentious Politics. New York, Cambridge. 
BENNETT, W. Lance; SEGERBERG, Alexandra; WALKER, Shawn (2014), "Organization in the crowd: peer production in large-scale networked protests". Information, Communication \& Society, v. 17, n. 02, pp. 232-260 [Consult. 21-12-2020]. Disponível em https://www.tandfonline.com/doi/full/10.1080/1369118X.2013.870379

BIMBER, Bruce; STOHL, Cynthia and FLANAGIN, Andrew (2009), "Technological change and the shifting nature of political organization", in, Chadwick, A. and Howard, P. The Routledge Handbook of Internet Politics. New York, Routledge, pp. 72-85.

CARDON, Dominique (2012), A Democracia Internet. Promessas e Limites. Rio de Janeiro, Forense Universitária.

CASTELLS, Manuel (2003), A Galáxia da Internet. Rio de Janeiro, Jorge Zahar.

CASTELLS, Manuel (2013), Redes de indignação e esperança: Movimentos sociais na era da internet. Rio de Janeiro, Zahar.

DOS SANTOS, Wanderley Guilherme (2017), A democracia impedida: o Brasil no século XXI. Rio de Janeiro, Editora FGV.

EARL, Jennifer; KIMPORT, Katrina (2011), Digitally Enabled Social Change. Massachusetts, The MIT Press.

FERREIRA, Maria Alice S. (2015), \#BHNASRUAS: uma análise do confronto político contemporâneo a partir de páginas do Facebook. Dissertação (Mestrado em Ciência Política). PPGCP, UFMG, Belo Horizonte. 198p.

FERREIRA, Maria A.; CREPALDE, Neylon (2017), "Mídias sociais e polarização política: a repercussão da PEC 55 no Twitter e no Facebook". Trabalho apresentado no $41^{\circ}$ Encontro Anual da Anpocs, Caxambu-MG.

FERREIRA, Maria A. PEREIRA, Matheus (2019), "Mulheres contra Bolsonaro: análise de redes do movimento \#EleNão e a produção de narrativas no Twitter". Trabalho apresentado no $8^{\circ}$ Congresso da Associação Brasileira em Comunicação e Política - Compolítica, Brasília-DF [Consult. 22-12-20]. Disponível em http://compolitica.org/novo/anais2/anais-2019/

GERBAUDO, Paolo (2016a), "Social media teams as digital vanguards: the question of leadership in the management of key Facebook and Twitter accounts of Occupy Wall Street, Indignados and UK Uncut", Information, Communication \& Society, v. 20, n. 02 pp. 185-202

GERBAUDO, Paolo (2016b), "Rousing the Facebook Crowd: Digital Enthusiasm and Emotional Contagion in the 2011 Protests in Egypt and Spain". International Journal of Communication, v. 10, pp. 254-273 [Consult. 21-12-2020]. Disponível em https://ijoc.org/index.php/ijoc/article/view/3963/1537

JASPER, Jasper (2014), "Emotions, Sociology and Protest". In: Von Scheve, Christian and Salmela, Mikko. Colletive Emotions: Perspectives from Psychology, Philosophy, and Sociology. Oxford, Oxford University Press, pp. 341-355.

LIM, Merlyna (2012), "Clicks, Cabs, and Coffee Houses: Social Media and Oppositional Movements in Egypt, 2004-2011". Journal of Communication v .62, n. 02, pp. 231-248 [Consult. 21-12-20]. Disponível em https://onlinelibrary.wiley.com/doi/abs/10.1111/j.1460-2466.2012.01628.x 
LIMONGI, Fernando (2017), "Impedindo Dilma”. Novos Estudos, v. Dinâmicas da Crise, no Edição Especial, pp. 5-13 [Consult. 21-12-20]. Disponível em http://novosestudos.com.br/wpcontent/uploads/2017/06/IMPEDINDO-DILMA-Fernando-Limongi.pdf

MANUAL DE INSTRUÇOES PARA FILIAIS MUNICIPAIS - MBL (2015), Manual de instruçõe. [Consult. 22-12-20]. Disponível em https://pt.scribd.com/doc/277263728/Manual-de-

MENDONÇA, Ricardo Fabrino (2017), "Singularidade e identidade nas manifestações de 2013". Revista do Instituto de Estudos Brasileiros [Online] n. 66, pp. 130-159 [Consult. 21-12-2020]. Disponível em https://www.scielo.br/pdf/rieb/n66/2316-901X-rieb-66-00130.pdf

MILAN, Stefania (2015), "When Algorithms Shape Collective Action: Social Media and the Dynamics of Cloud Protesting". Social Media + Society, v. 1, n. 2, pp. 1-10 [Consult. 21-12-2020] Disponível em https://journals.sagepub.com/doi/pdf/10.1177/2056305115622481

SANTIAGO, Ariadne; VON BÜLOW, Marisa; DIAS, Tayrine S.; GOMES, Alexandre (2017), "Impeachment ou Golpe? Disputas por Significados no Twitter". Trabalho apresentado no III Encontro Internacional Participação, Democracia e Políticas Públicas: Vitória/ES.

SCHRADIE, Jen (2019), The revolution that wasn't. How digital activism favors conservatives. Cambridge, Massachusetts, Havard University Press.

TARROW, Sidney (2013), The Language of Contention. Revolution in Words, 1688-2012. New York, Cambrigde University Press.

VAN DIJCK, José (2012), "Facebook as a tool for Producing Sociality and Connectivity". Television and New Media, v. 13, n. 2, pp. 160-176 [Consult. 22-12-20]. Disponível em https://journals.sagepub.com/doi/10.1177/1527476411415291

VAN DIJCK, José; POELL, Thomas (2013), "Understanding Social Media Logic". Media and Communication, v. 1 , pp. 2-14 [Consult. 22-12-20]. Disponível em https://www.cogitatiopress.com/mediaandcommunication/article/view/70

VON BULOW, Marisa; VILAÇA, Luiz; ABELIN, Pedro Henrique (2018), "Varieties of digital activist practices: students and mobilization in chile". Information, Communication \& Society, v. $22, \quad$ n. 12, pp. 1770-1788 [Consult. 22-12-20]. Disponível em https://www.tandfonline.com/doi/abs/10.1080/1369118X.2018.1451550 


\begin{abstract}
This work sought to identify the dynamics of mobilization on pages of different political spectrum during the period of protests. To this end, we analyzed the content of the Facebook pages of the Movimento Brasil Livre and Frente Brasil Popular seeking to understand the strategies of communication and the use of affordances of the pages between March and April of 2016, a period marked by intense demonstrations in favor and against the impeachment of Dilma Rousseff. In the analysis, we tried to identify the following elements: 1) number of posts; 2) engagement; 3) posted content; 4) subjects covered; 5) posts with reference to President Dilma; 6) use of hashtags; 7) sources; 8) type of media and 9) invitations to donate and participate in the movement. It is concluded that there were very different strategies in the use of affordances compared to the two movements.
\end{abstract}

Keywords: impeachment; Frente Brasil Popular; Movimento Brasil Livre; Facebook.

\title{
Resumen
}

Este trabajo buscó identificar las dinámicas de movilización en diferentes páginas del espectro político durante el período de protestas. Para ello, analizamos el contenido de las páginas de Facebook del Movimento Brasil Livre y del Frente Brasil Popular con el fin de comprender las estrategias de comunicación y el uso de las affordances de estas páginas entre marzo y abril de 2016, un período marcado por intensas manifestaciones en contra y a favor de la acusación de Dilma Rousseff. En el análisis, intentamos identificar los siguientes elementos: 1) número de publicaciones; 2) participación en el post; 3) contenido publicado; 4) temas cubiertos; 5) referencia a la presidenta Dilma; 6) uso de hashtags; 7) fuentes; 8) tipo de medios y 9) invitaciones para donar y participar en el movimiento. Se concluye que hubo estrategias muy diferentes en el uso de las affordances al comparar los dos movimentos.

Palabras clave: impeachment; Frente Brasil Popular; Movimento Brasil Livre; Facebook. 